ISSN: 0514-7336 — ISSN electrónico: 2386-3943

DOI: https://doi.org/10.14201/zephyrus202188111134

\title{
DOMEÑANDO EL TIEMPO Y EL ESPACIO. LA INSTRUMENTALIZACIÓN DEL RITO Y LA MEMORIA EN LA NECRÓPOLIS DE LA ALBUFERETA, ALICANTE, EN EL S. III A. C.
}

\section{Mastering Time and Space: Exploitation of Ritual and Memory in the

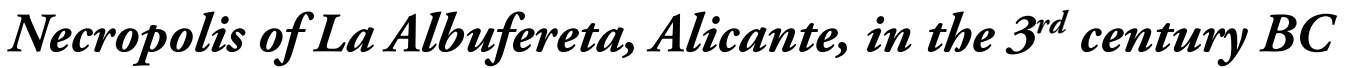

\author{
Jorge García Cardiel
}

Dpto. de Historia Antigua, Historia Medieval y Paleografía y Diplomática. Facultad de Filosofía y Letras. Univ. Autónoma de Madrid. Avda. Tomás y Valiente, 1. 28049 Madrid. Correo-e: jorge.garciac@uam.es. ID ORCID: https://orcid.org/0000-0002-1093-8129

Recepción: 25/02/2021; Revisión: 9/07/2021; Aceptación: 15/10/2021

Resumen: La revisión pormenorizada de los materiales del depósito L127A de la necrópolis de La Albufereta y de la documentación disponible sobre su excavación permite matizar algunas cuestiones planteadas sobre su funcionalidad, cronología y significado. No se trataría de un conjunto fechado a comienzos del s. IV a. C., como generalmente se ha dado por sentado a partir de las importaciones áticas, sino que debe datarse en la segunda mitad del s. III a. C., pese a que para entonces algunos de los materiales amortizados fueran reliquias. Los restos evidencian la celebración de un ritual en el que se cremaron numerosos objetos cuidadosamente seleccionados, de procedencia y cronología diversas, y con fuertes connotaciones funerarias y mistéricas. Los responsables del rito buscarían enfatizar así su 'distinción' en unos momentos particularmente convulsos a escala local y regional.

Palabras clave: Segunda Edad del Hierro; iberos; cartagineses; religión; reliquias; tanagras; cerámicas áticas; hibridación.

AвSTRACT: A detailed analysis of the artifacts included in the deposit L127A of the necropolis of La Albufereta, as well as the available documentation on its discovery, reveal a more nuanced picture about its functionality, chronology and meaning. It cannot be dated in the early $4^{\text {th }}$ century BC, as is generally supposed on the basis on the Attic pottery, but in the second half of the $3^{\text {rd }}$ century BC. By then, the Attic wares must have been genuine relics. The archaeological record shows the celebration of a rite in which several carefully chosen objects were cremated. Those objects had different origins and chronologies, and they had strong funerary and mystery connotations. The people responsible for the rite may try to highlight their 'distinction' at a particularly troubled time at local and regional level.

Key words: Second Iron Age; Iberians; Carthaginians; Religion; Relics; Tanagra figurines; Attic pottery; hybridization. 


\section{Introducción ${ }^{1}$}

Pese a tratarse de una de las primeras necrópolis ibéricas en ser excavada en extensión, o precisamente por eso, el cementerio de La Albufereta, Alicante, continúa suscitando numerosos interrogantes a la investigación.

Ya lo hizo desde los mismos momentos de su excavación entre 1931 y 1935, cuando la peculiaridad de sus hallazgos llevó a sus excavadores a proponer el culto en tierras alicantinas de una divinidad femenina de la fecundidad y del Más Allá impregnada del universo religioso púnico (Belda, 1947), o bien directamente a emplear el yacimiento como argumento para avalar una supuesta presencia cartaginesa en el lugar (Figueras, 1952a; Lafuente, 1957: 50-55; Nordström, 1961: 47-87; contra, Llobregat 1972: 76-77). Entre los años setenta y ochenta Rubio (1986) realizó un prolijo trabajo de sistematización de los materiales en el que trató de determinar a qué sepultura pertenecía cada cual. En los últimos quince años, por último, Verdú (2015) ha actualizado y depurado los trabajos de Rubio, completándolos además con una mayor carga analítica. Todo lo cual, empero, no ha servido para agotar el potencial interpretativo de esta sorprendente necrópolis.

Por nuestra parte, dedicaremos estas páginas al estudio de un conjunto de este cementerio, el L127; un conjunto que en el momento de su excavación ya destacó por la espectacularidad y riqueza de sus materiales, pero también por los graves problemas interpretativos que la asociación de estos planteaba. Ambos factores condujeron hace ya unos años a Olmos (2000-2001, 2006, 2007; Olmos y Tortosa, 2010) a profundizar en el asunto. Estimamos, no obstante, que una nueva revisión del depósito a la luz de los nuevos paradigmas interpretativos nos

1 Grupo Occidens. Quiero expresar mi más sincero agradecimiento a $\mathrm{R}$. Olmos, quien me sugirió la idea de redactar estas páginas, facilitó que la investigación pudiera llevarse a cabo y la amparó con un sinfín de interesantes ideas. Y doy las gracias asimismo al Museo Arqueológico de Alicante -en adelante MARQ- y a su personal, especialmente a su director, M. H. Olcina, y a E. Verdú, por facilitar mi trabajo en sus instalaciones y el acceso a los materiales. permitirá comprender mejor las singulares dinámicas políticas, sociales y religiosas de la comunidad que habitaba en las cercanías, y la forma en la que las elites locales trataron de instrumentalizar el pasado y la memoria colectivos en una coyuntura de rápidas transformaciones sociopolíticas como la que caracterizó las últimas décadas del s. III a. C.

\section{La necrópolis de La Albufereta: localización y cronología}

El cementerio de La Albufereta se encuentra al o del término municipal de Alicante, en el extremo de una pequeńa ensenada encerrada entre la Sierra Grossa y el Cabo de la Huerta, junto a la playa y justo a los pies del Tossal de Manises. Se trata de una zona muy transformada, pues hasta el s. XIX toda esta depresión estuvo ocupada por una pequeña albufera que según los estudios sedimentológicos habría funcionado como una laguna con intensa comunicación con el mar durante el Ibérico Antiguo, y como un medio pantanoso cerrado por una restinga arenosa en época Ibérica Plena y durante la ocupación romana (Ferrer, 2005: 124-126). Una zona que, sin embargo, se ha considerado tradicionalmente un excepcional puerto natural, rico en caza y pesca y situado en el extremo de las vías naturales que conectan la costa con los valles alcoyanos y el Alto Vinalopó (Mula y Rosser, 1993: 103-105).

Esto último explicaría al menos en parte la llamativa concentración de yacimientos que encontramos en el enclave. Así, observamos que en las primeras estribaciones de Sierra Grossa, a menos de $300 \mathrm{~m}$ de la necrópolis, pero al otro lado de la depresión otrora pantanosa, se ubicó el Tossal de les Basses, un asentamiento costero amurallado en el que se desarrolló una importante actividad portuaria, comercial y artesanal entre el s. vi y la primera mitad del III a. C. (Rosser y Fuentes, 2007). Frente al Tossal de les Basses pero ya del otro lado del área pantanosa se yergue el Tossal de Manises, justo por encima de la necrópolis de La Albufereta (Olcina et al., 2020). Sobre este cerro floreció un asentamiento amurallado que durante los primeros años del 
principado de Augusto fue promocionado al rango de municipio romano con el nombre de Lucentum (Alföldy, 2003: 47). Ahora bien, la fecha de su fundación resulta más problemática pues, aunque en la cima del altozano se han documentado algunas cerámicas áticas de finales del s. v y el s. Iv a. C., los últimos estudios evidencian que el asentamiento se fundó en la segunda mitad del s. III a. C. como un puesto de avanzadilla cartaginés, poblado y seguramente gestionado por gentes locales -quizás los antiguos habitantes del Tossal de les Basses, abandonado aproximadamente por esas fechas- aliadas de Cartago (Olcina et al., 2010: 232-234; 2014: 127-128; 2017: 286-302; 2020: 55-83). Esta primera fase del Tossal de Manises, no por casualidad, sería destruida a finales del s. III o comienzos del II a. C. (Olcina et al., 2020: 77-81) (Fig. 1).
Gracias a algunas indicaciones dispersas por la bibliografía, hemos intentado cartografiar las intervenciones de Lafuente y Figueras entre 1932 y 1935, con objeto de poder hacernos una idea de la extensión y localización del área excavada (Fig. 2). Comprobamos así que Lafuente centró sus investigaciones al so de la carretera cuya construcción motivó la excavación, en tanto que Figueras hizo lo propio al NE. No obstante, ignoramos cuáles serían los límites originales de la necrópolis, cuyo potencial arqueológico no parece que llegara a agotarse (Verdú, 2005: 32; 2015: 57; 2018: 161-176; cf. contra, Belda, 1947: 240), ni tampoco sabemos en qué áreas se produciría una mayor densidad de hallazgos, pues solo conocemos la distribución de los depósitos documentados por Figueras.

Otro espinoso aspecto de la necrópolis de La Albufereta es el de su cronología. Belda (1947: 241)

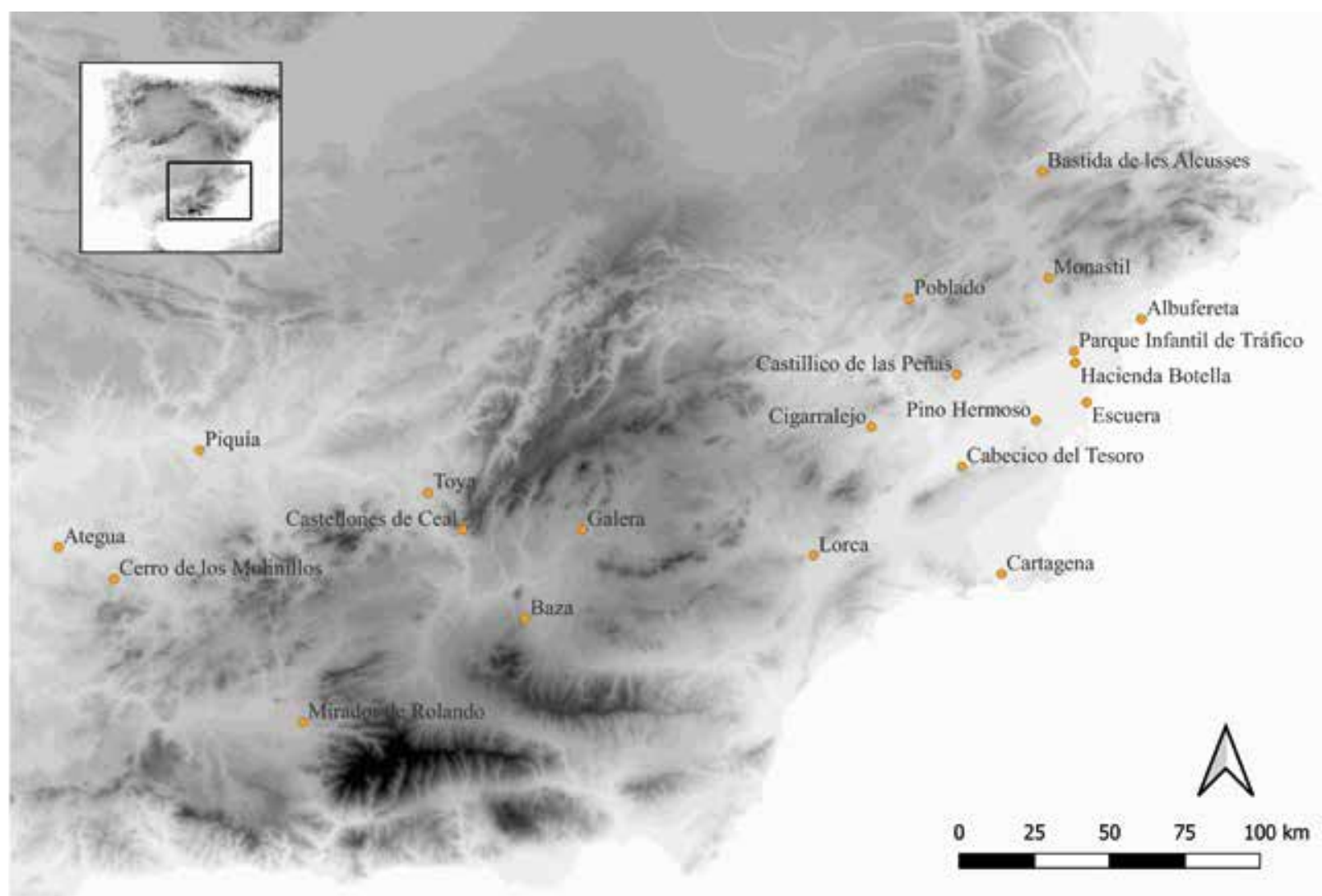

FIG. 1. Principales yacimientos mencionados en el texto. 


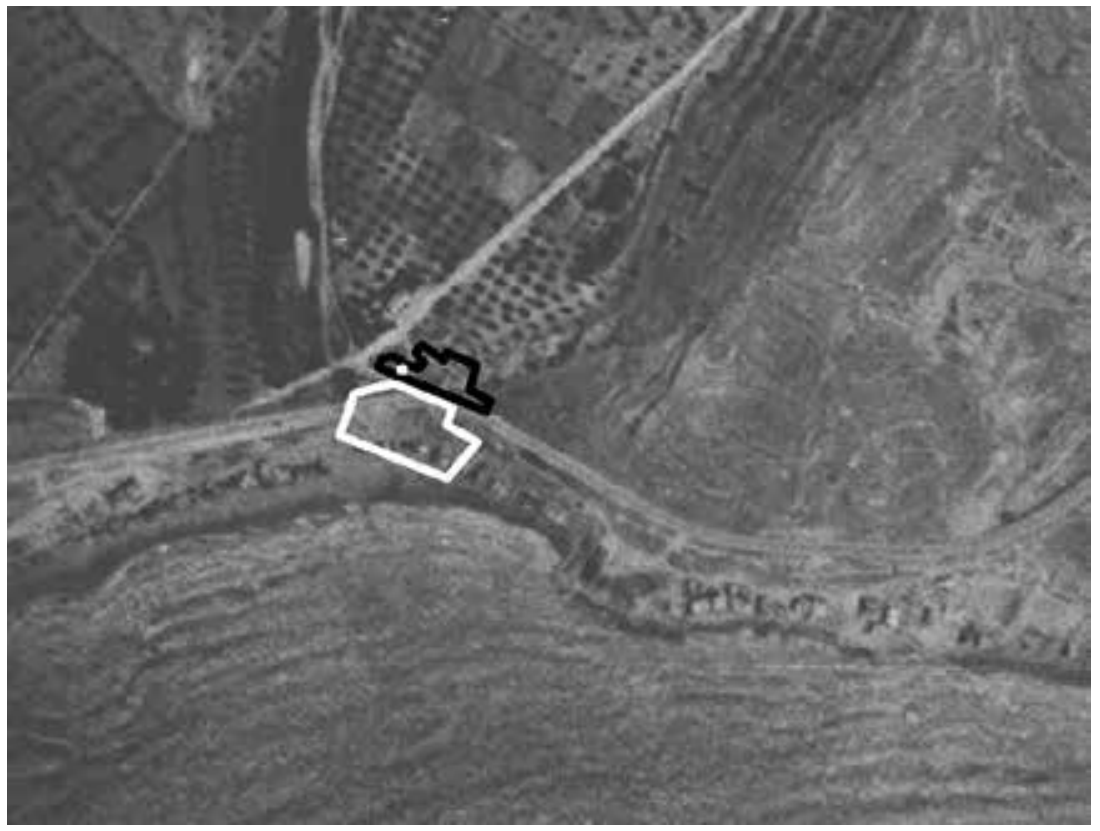

Fig. 2. Estimación del área excavada de la necrópolis de La Albufereta; en blanco la intervención de J. Lafuente y en negro la de F. Figueras (proyectada sobre fotografía aérea de 1946 proporcionada por el IGN).

sostuvo que la mayoría de las sepulturas documentadas databan del s. III a. C., si bien se habían hallado algunos enterramientos del s. IV a. C. y del II a. C. Más categórico fue Figueras, para quien la necrópolis tan solo permaneció en uso durante el s. III a. C. (Figueras, 1936: 5) o, más concretamente, durante el último tercio de dicha centuria (Figueras, 1947: 230). Ambos autores, por tanto, y como ya hiciera Lafuente, pusieron en relación la frecuentación de la necrópolis con la presencia cartaginesa en el SE peninsular.

La revisión de los materiales que llevó a cabo Rubio le sirvió, no obstante, para proponer que la necrópolis se habría mantenido en uso entre los primeros años del s. IV a. C. y mediados del III a. C.; es más, de los 54 depósitos que considera fechables, según él 41 pertenecerían con seguridad al s. IV a. C., siendo los más antiguos los conjuntos F25, f54 y L127 (Rubio, 1986: 384-386). Por su parte, Verdú (2015: 478) defiende que la necrópolis fue frecuentada entre el s. IV y las primeras décadas del II a. C., aunque sitúa el momento de auge del yacimiento a lo largo del s. III a. C. También para

Ediciones Universidad de Salamanca / @ه্త este investigador destaca por su antigüedad el depósito L127.

Dejando a un lado, aunque sin perderlos de vista, los distintos presupuestos de partida de los distintos autores, es evidente que entre sus trabajos median 80 años de refinamiento de nuestros conocimientos sobre la cultura material ibérica. Así, si las dataciones de Rubio tomaron en cuenta fundamentalmente las cerámicas áticas, las de Verdú contrastan los datos ofrecidos por estas con los derivados de las producciones propiamente ibéricas. Ahora bien, dado que las tipologías ibéricas no están aún tan desarrolladas como nos gustaría, y dado que dichas tipologías en realidad se elaboraron basándose en la conexión de los distintos artefactos ibéricos con cerámicas de importación áticas e itálicas, colegiremos que incluso en los estudios más recientes los materiales foráneos se imponen todavía como el principal elemento de referencia cronológica. Algo que, tal y como se viene poniendo cada vez más de manifiesto en la arqueología ibérica, entraña graves dificultades (Ruiz et al., 2015).

Ciertos trabajos monográficos sobre determinados tipos de materiales han contribuido a matizar la cronología de la necrópolis de La Albufereta. Así sucede con las terracotas, datables generalmente en la segunda mitad del s. III a. C. (Horn, 2011: 240243), o con las importaciones cerámicas del s. III a. C. (Sala, 1998: 41-42). En un reciente estudio, de hecho, alertábamos sobre la circunstancia de que la mitad de los depósitos con materiales áticos de los ss. v y IV a. C. de La Albufereta contenían asimismo objetos fechables en la segunda mitad del s. III a. C., mientras que la otra mitad carecía de ulteriores materiales diagnósticos que respaldaran las dataciones de las cerámicas áticas (García Cardiel, 2017; contra, Olcina et al., 2020: 86-87). Así pues, debemos 
concluir que al menos una parte de las cerámicas áticas empleadas tradicionalmente para fechar este yacimiento eran ya viejas en el momento en el que se amortizaron, lo que redunda en la impresión formulada por Verdú de que el momento de mayor auge de la necrópolis se correspondería con el s. III a. C. Acaso, añadiríamos, con su segunda mitad.

Pero, más allá de los abundantes materiales romanos entreverados en los estratos superficiales del yacimiento -esperables en la periferia de un municipio encaramado sobre un monte-, la cuestión se torna todavía más confusa si atendemos a ciertas cerámicas de importación llamativamente antiguas: una crátera de columnas de figuras negras, datable en el último cuarto del s. vi a. C. (García i Martín, 1996), у una copa jonia в2 del segundo tercio del s. vi a. C. (Rouillard, 1976: fig. 1). Y más espectaculares aún resultan los restos arquitectónicos y escultóricos distribuidos por el lugar, como el fragmento de voluta de gola datable grosso modo en el s. $\mathrm{v}$ a. C. (Castelo, 1995: 179-180) o el toro del Grupo 1 de Chapa (2005-2006), fechable en el s. vi a. C. No creemos que a partir de tan escasos vestigios sea posible colegir la frecuentación de la necrópolis a partir del s. vi a. C., como en ocasiones se ha propuesto (Ramón, 2007: 108-109), pero tampoco podemos olvidarnos de su existencia a la hora de interpretar el yacimiento.

$\mathrm{Y}$ es que ya desde las excavaciones de Lafuente y Figueras -que, no lo olvidemos, simultanearon la intervención en ambos enclaves- se asumió que La Albufereta era la necrópolis del Tossal de Manises, y semejante modelo apenas se ha cuestionado desde entonces. Pero ya hemos señalado que las últimas investigaciones proponen una fecha de fundación del Tossal de Manises encuadrable en el último tercio del s. III a. C., mientras que algunos enterramientos de La Albufereta podrían retrotraerse al s. IV a. C., y los elementos escultóricos, arquitectónicos y cerámicos aislados nos hablan de una frecuentación del enclave cuando menos del s. vI a. C. Ahora bien, a menos de trescientos metros de la necrópolis, aunque al otro lado de la zona inundada, se encuentra el Tossal de les Basses, datable precisamente entre el s. vi y mediados del III a. C.

Ediciones Universidad de Salamanca / 요요
En torno a este asentamiento se han documentado ya algunas tumbas, pero nada impediría que el poblado tuviera varias áreas cementeriales (Rosser y Ortega, 2008: 17). La Albufereta, por tanto, pudo funcionar en un primer momento como un lugar sagrado situado en la periferia del Tossal de les Basses, visible desde el asentamiento, pero al otro lado de la laguna, en el que a partir de un momento dado comenzarían a excavarse sepulturas. Y cuando aquel poblado se abandonó y se fundó el enclave de Tossal de Manises -quizás en parte con la población de aquel-, nada hubo de parecer más lógico que continuar empleando como tal el área funeraria de La Albufereta (Verdú, 2015: 55; Olcina et al., 2020: 84).

\section{El conjunto L127. Descripción e inventario}

Dentro de esta necrópolis, nos gustaría llamar la atención sobre el conjunto L127, una acumulación de hogueras y depósitos cubierta por un túmulo de arena y piedras que se alzaba uno o dos metros sobre la altitud de la playa. En el momento de su descubrimiento, el extremo oriental del túmulo había sido ya cubierto por el terraplén de la carretera de San Juan (Lafuente, 1934: 24), por lo que no pudo ser excavado por completo ni pudo cuantificarse con exactitud su superficie.

Bajo este túmulo, se descubrieron toda una serie de restos arqueológicos de compleja -y problemática- descripción ${ }^{2}$ (Fig. 3). Para empezar, aquí apareció el depósito conocido tradicionalmente como la 'Gran Sepultura'. Lo denominaremos L127A, empleando el nombre que en su momento consagrara la tesis de Rubio. Hablamos de una gran hoguera de planta irregular y 1,8 m de diámetro, en cuyo extremo occidental se documentaron dos hileras de adobes separados unos $20 \mathrm{~cm}$ entre sí, y que en su momento fueron interpretados como los restos de un hornillo. En el extremo oriental, por su parte, se descubrió una gran piedra cónica de 1,20 m de

2 Cf. Lafuente (1934: 22-24) para la descripción de los hallazgos en este y los siguientes párrafos. También vid., para su contrastación, Rubio, 1986: 214-232; Verdú, 2015: 68 y $451-452$. 


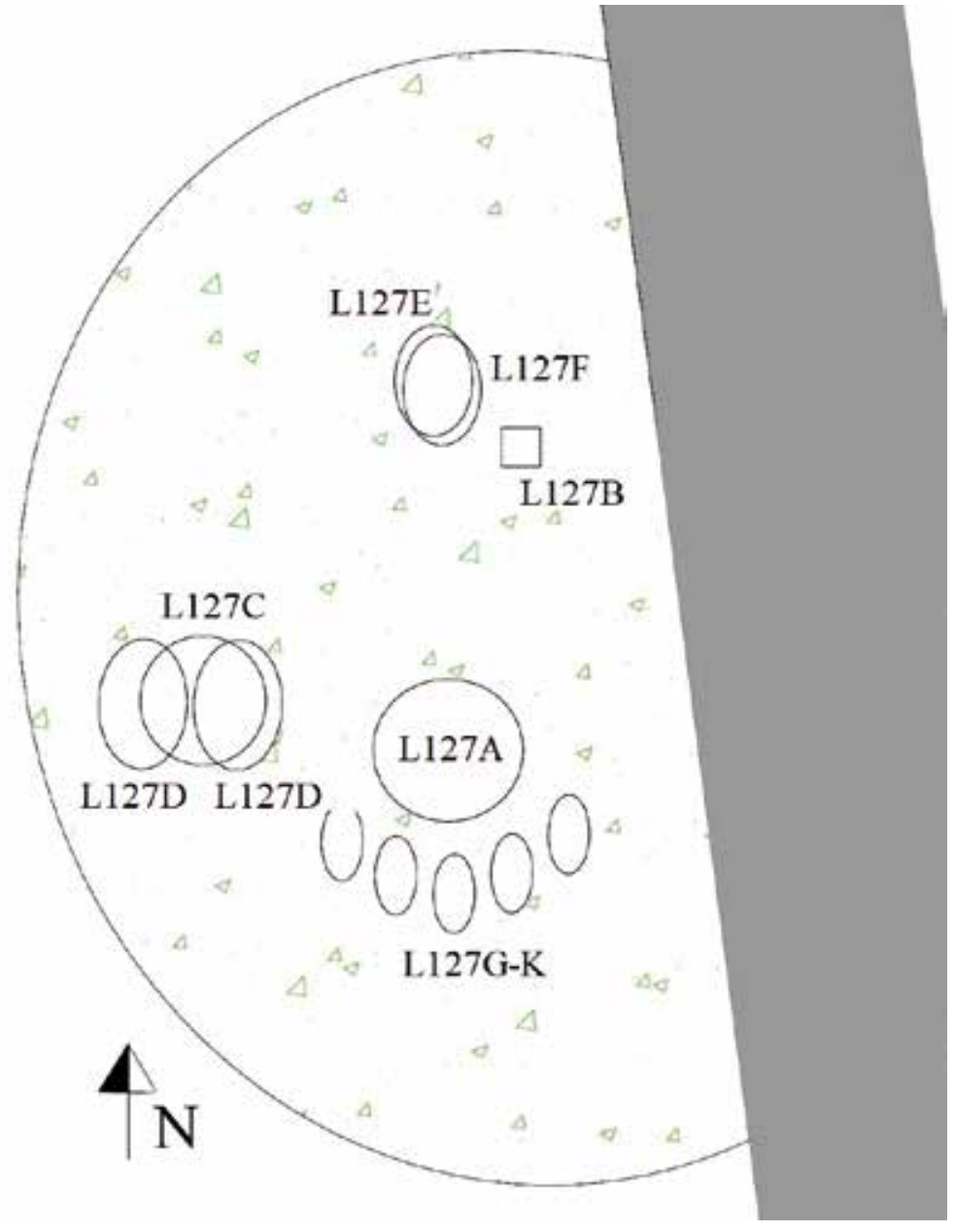

Fig. 3. Esquema de la disposición de los depósitos que conformaron el conjunto L127 de la necrópolis de La Albufereta.

longitud, traída de lejos según sus excavadores, aunque este extremo no ha podido verificarse dado que, por lo que sabemos, la piedra no se ha conservado. Entre ambos elementos, y entremezclados con una enorme cantidad de carbones, aparecieron, según recoge Lafuente, 10 pebeteros, 17 ungüentarios, entre 6 y 8 tanagras con imágenes de diosas, una representación en barro de un ojo, varias tabas, cuentas de pasta vítrea, bolas de barro cocido, fusayolas, diversos vasos ítalo-griegos y campanienses, algunos restos de bronce y hierro -que Lafuente interpretó como restos de un trípode y una pala- y un juego de platos y 'candeleros' de plata. A este inventario, Belda (1947: 245) añadió varios aretes de oro, armas de hierro, 1 arqueta carbonizada con apliques de hueso, 1 'Casita del alma', 1 ollita íbero-púnica en forma de granada, 1 medallón de bronce con una representación de Hércules en pasta vítrea y 3 'hornillas' de hierro, una de ellas cubierta por un platillo de bronce sobre el que reposaba un paño de lana carbonizado; precisó, además, que los vasos ítalo-campanienses mencionados por Lafuente eran 2 kýlikes y 1 plato-tapadera adornado con animales. Repárese en que ninguno de los dos investigadores mencionó la existencia de restos humanos ${ }^{3}$.

En torno a esta 'Gran Sepultura', rodeándola por el $\mathrm{s}$, aparecieron cinco enterramientos -L127G-L127 K- de entre 0,9 y $1 \mathrm{~m}$ de longitud, y entre 0,35 y $0,6 \mathrm{~m}$ de anchura. En torno a esta 'Gran Sepultura', rodeándola por el $\mathrm{s}$, aparecieron cinco enterramientos $-\mathrm{L} 127 \mathrm{~g}$-L $127 \mathrm{k}$ - de entre 0,9 y $1 \mathrm{~m}$ de longitud, y entre 0,35 y $0,6 \mathrm{~m}$ de anchura. Ninguno de estos materiales pudo ser identificado por Rubio y Verdú entre los conservados en el Museo. En los que, además de los correspondientes restos óseos, se amortizaron armas, broches de cinturón, cuentas de pasta vítrea y 2 ungüentarios. Ninguno de estos materiales pudo ser identificado por Rubio y Verdú entre los conservados en el Museo.

3 De todos estos materiales, no aparecen en los recuentos que posteriormente hicieran Rubio (1986: 215232) y Verdú (2015: 451-452) ni, por lo que hemos podido comprobar, se conservan depositados en el MARQ 7 de los 10 pebeteros, 1 de las 3 kýlikes, las cuentas, las fusayolas, las tabas, la cerámica campaniense, la vajilla de plata, la ollita en forma de granada, las armas, las hornillas de hierro, el platillo de bronce ni el paño de lana. Por el contrario, colegimos que la 'Casita del Alma' mencionada por Belda alude a la terracota de la cueva, que el aplique de marfil conservado pertenecería a la caja carbonizada y que alguna de las 'bolas de barro cocido' podría corresponder a la pequeña granada conservada. Por lo demás, a este inventario hemos de añadir el vaso doble y el llamado tonelete doble. 

y la memoria en la necrópolis de La Albufereta, Alicante, en el s. III a. C.

A 2 m de la 'Gran Sepultura' se documentaron otras tres hogueras. Una de ellas $-\mathrm{L} 127 \mathrm{C}-$, de 1,6 x 0,9 m, contenía según Lafuente una gran urna cineraria -en realidad un gran pithos decorado-, en cuyo interior apareció, junto con los restos óseos del difunto y gran cantidad de cenizas y carbones, una 'imagen de la diosa' - un nuevo pebetero- y varios fragmentos de cáscara de huevo de avestruz. Superpuestas a esta hoguera se excavaron otras dos sepulturas $-\mathrm{L} 127 \mathrm{D}-$, prácticamente simétricas entre sí, en cuyo interior se halló una gran cantidad de carbones, restos de cáscara de huevo de avestruz, sendas urnas cinerarias, tres fíbulas hispánicas y diversos vestigios de lanzas, falcatas y soliferrea. Lamentablemente, de estas dos hogueras solo se conservan en la actualidad las mencionadas fíbulas.

Al otro lado de la susodicha 'Gran Sepultura', a 3 m de ella, Lafuente describe un nuevo subconjunto, una hoguera que el arqueólogo calificó de 'ustrinum' -L127E-, y que constaba de una bolsada de ceniza enmarcada por cuatro adobes y en la que también aparecieron los restos de un soliferreum y una lanza, que no se han conservado. Superpuesta a esta hoguera se documentó un segundo depósito -L127F- compuesto de carbones, diverso material cerámico, tabas, objetos de hierro de funcionalidad desconocida y un 'ritón' -esto es, un guttus de barniz negro, la única pieza conservada-. Junto a estas dos hogueras superpuestas y en relación con ellas ${ }^{4}$ se situó un nuevo depósito -L127B-, en este caso cuadrado y de pequeñas dimensiones, en cuyo interior solamente se documentó una cuenta vítrea.

Por último, Lafuente añade que a lo largo de toda la superficie cubierta por el túmulo se excavaron otras muchas sepulturas, de entre 1,2 y $1,8 \mathrm{~m}$ de longitud y 0,5 y $0,9 \mathrm{~m}$ de anchura, cuyos ajuares funerarios comprendían cuentas de pasta vítrea, fusayolas, discos de plata, botones de bronce, fíbulas, armas, 'imágenes de diosas' - ¿pebeteros? ¿tanagras?-, cerámica helenística y campaniense, vajilla ibérica, elementos informes de bronce y una moneda de Gades con la figuración de un delfín. Por desgracia, de todo este conjunto material solo han podido identificarse 2 pebeteros con forma de cabeza femenina entre los fondos del Museo.

4 Y no con la 'Gran Sepultura', como asume Rubio (1986: 215).

Ediciones Universidad de Salamanca / @क@요

\section{El problema de la cronología del conjunto L127}

La determinación de la cronología del conjunto L127 de La Albufereta resulta especialmente problemática, pues en él se acumularon materiales de muy diversas épocas, y resulta además complejo concretar las relaciones temporales existentes entre las distintas hogueras. La desaparición de muchos de los materiales -y de los cuantiosos carbones documentados-, unida a la inexistencia de registros estratigráficos detallados, dificulta la propuesta de conclusiones categóricas al respecto.

Pero veamos con más detenimiento los objetos conservados, comenzando por los documentados en L127A. Las dos kýlikes áticas de figuras rojas ${ }^{5}-$ Tipos к у в de Lattara = Sparkes-Talcott 433- han sido datadas a finales del s. v a. C. y atribuidas al Pintor de Londres e 106 (Trías, 1967: 365, láms. ClXIX y CLXX, 1), artista al que también se le asigna una kýlix bastante similar a estas conservada en el Ashmolean Museum de Oxford (Beazley, 1963: 1391, 4). Estas producciones de gran calidad se distribuyeron preferentemente por Grecia, Italia central y septentrional y el Golfo de León, en tanto que al s de Ampurias únicamente se conocen estos 2 ejemplares, lo que hace que su presencia conjunta en el depósito L127A resulte aún más llamativa.

La tapadera de lékane $e^{6}$ de figuras rojas -Tipo Sparkes-Talcott 1226-1241- se atribuye al grupo de la Lékane de Viena, con cronologías comprendidas entre finales del s. v y primer cuarto del Iv a. C. (Trías, 1967: 369, lám. ClXxiv) o alcanzando ya quizás el segundo cuarto del s. IV a. C. (Olmos, 2007: 380). Han aparecido otras tapaderas similares con decoraciones análogas en la Tumba 146 de Poblado, en Coimbra del Barranco Ancho, Murcia (García Cano y Gil, 2009: 83), y en el Departamento 2 de Bastida de les Alcusses, en Mogente, Valencia (Fletcher et al., 1965: 3435), y otros tantos fragmentos en Castillico de

5 N.o inv. cs6063 y 3639. En lo sucesivo, todos los códigos corresponden a los inventarios del MARQ.

$6 \operatorname{cs} 3614$. 

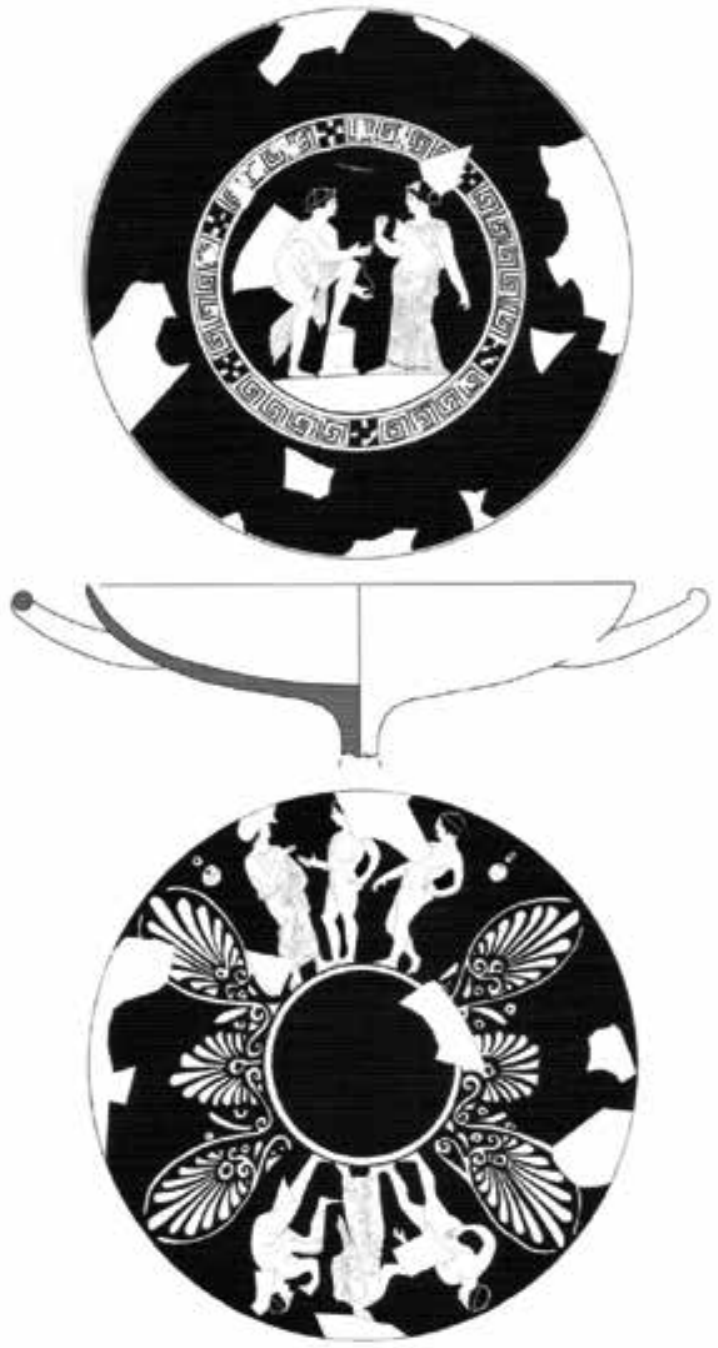
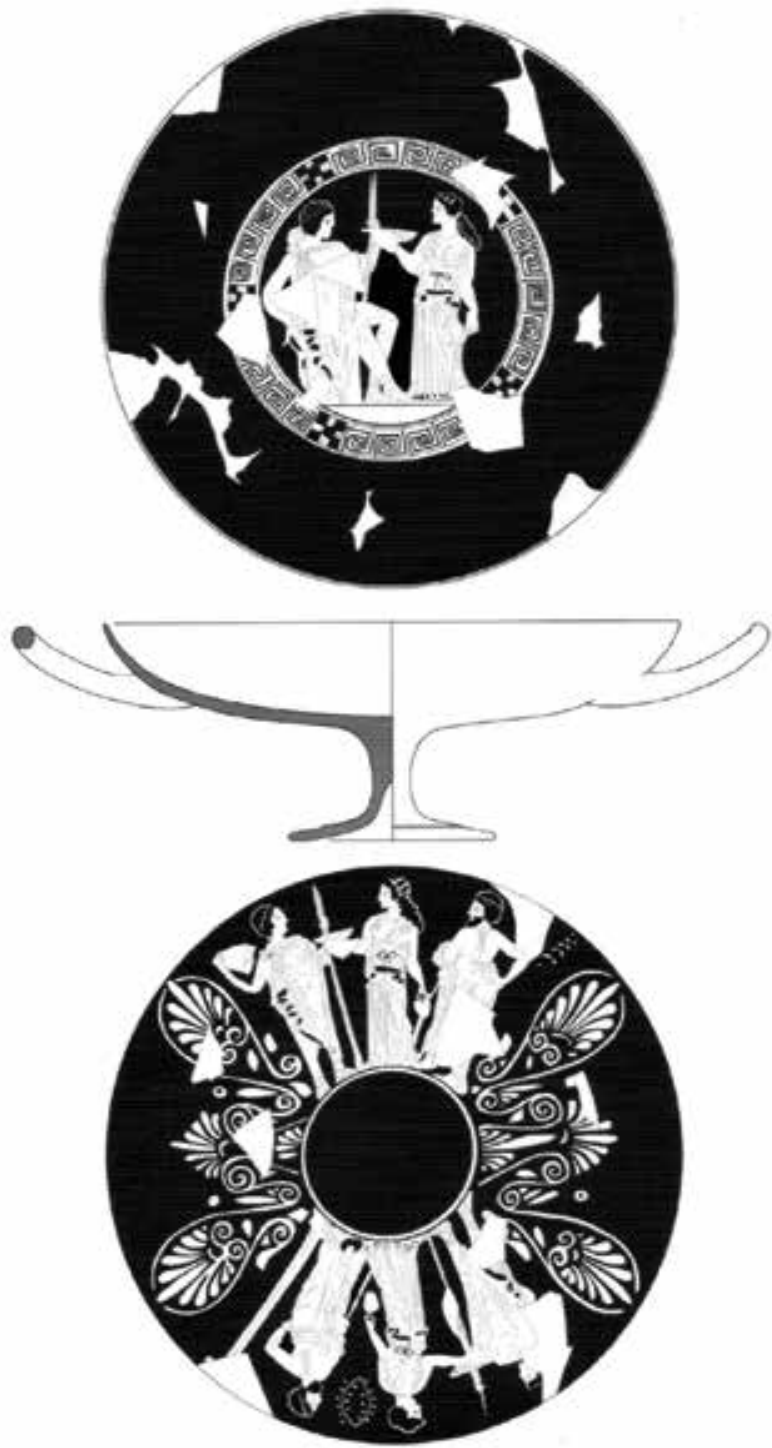

Fig. 4. Kýlikes áticas del conjunto L127 de la necrópolis de La Albufereta (según Verdú, 2015: 111).

las Peñas, en Fortuna, Murcia (Lillo, 1981: 227); Ullastret, Gerona (Picazo, 1977: 82), y Ampurias (La Escala, Gerona) (Miró, 2006: 701), por lo que García Cano y Gil (2009: 83-92) propusieron la identificación de un 'Pintor de la Lékane de Coimbra', sugiriendo que todas estas tapaderas pudieron llegar a Iberia formando parte de un mismo lote (Fig. 4).
El vaso doble $\mathrm{e}^{7}$ del tipo A-v.6.9 $9^{8}$ resulta prácticamente un hápax en la cultura material ibérica, pues solo puede argüirse para él un único paralelo, otro vaso doble que aparece, precisamente, en otra sepultura de La Albufereta, acaso datable, a partir de

$$
\text { cs3136. }
$$

8 Para la cerámica ibérica, seguiremos en lo sucesivo la tipología propuesta por Mata y Bonet (1992). 
2 cántaros y 4 cuencos áticos de barniz negro, en la segunda mitad del s. Iv a. C. (Verdú, 2015: 218219 y 481).

La escasez o la ausencia total de paralelos para las representaciones en terracota de la cueva, el ojo y la granada ${ }^{9}$ dificultan su datación. Lo mismo sucede con el medallón de bronce y pasta vítrea ${ }^{10}$, en tanto que la sencillez de la factura de los pendientes de oro $^{11}$ tampoco permite profundizar mucho más en este sentido. Otro tanto se puede decir del supuesto tonelete doble ${ }^{12}$, que en realidad no es sino una representación en miniatura de un tonel de arcilla -del Tipo 1 de Fletcher- cuya fragmentación en una de sus caras dio lugar a que se haya reconstruido como un tonelete geminado. Verdú (2015: 406) enumera varios paralelos para el aplique de marfil con la representación de un capitel jónico ${ }^{13}$ en diversas necrópolis púnicas centromediterráneas y en una tumba emporitana, datados entre los ss. IV y II a. C.

Conservamos, además, seis pasarriendas, una abrazadera de radios de una rueda y dos bielas de distintos diámetros y secciones ${ }^{14}$ pertenecientes a un carro (Verdú, 2015: 309-311 y 342-345). Conocemos otras ruedas de carros de tipología similar amortizadas en sepulturas de entre finales del s. v y el iII a. C., como las de Lorca, Fortuna, Baza, Mirador de Rolando, Galera y Toya (Fernández Miranda y Olmos, 1986), pero los paralelos más cercanos a nuestras piezas los tenemos en el departamento 236 de la Bastida de les Alcusses, donde encontramos un juego de 4 pasarriendas de idéntica tipología y dimensiones a los de La Albufereta, datados a lo largo del s. Iv a. C. (Quesada, 2011: 208 y 211-214), y también en los elementos del timón del carro recientemente descubierto en Montemayor (Córdoba), datable asimismo en el s. IV a. C. ${ }^{15}$. Resulta igualmente llamativo el parecido con los

cs3703, 6862 y 6859 respectivamente.

$10 \quad$ cs6067.

$11 \quad \operatorname{cs} 6098$ y 6101.

12 cs3697.

$13 \mathrm{Cs} 4804$

14 cs4310, 5201, 5177, 5198, 5199 y 5200; cs5203; cs5287 y 5288 .

15 Com. pers. de F. Quesada, a quien le agradezco el dato.

Ediciones Universidad de Salamanca / 요요 pasarriendas de Ategua, en Santa Cruz, Córdoba, datados hipotéticamente en el s. v a. C. (Jiménez y Muñoz, 1997: 130-134), pues también aquí las esquinas aparecen rematadas por palmetas similares -apreciables a simple vista solo en algunas piezas de La Albufereta, aunque un examen detallado nos ha demostrado que estarían presentes probablemente en todas ellas-. Por último, merece la pena reseñar el hallazgo de un pasarriendas de bronce en Piquía, Arjona, Jaén, asociado también en este caso a cerámicas áticas del s. v a. C., aunque incluido en un depósito del s. I a. C. (Ruiz Rodríguez et al., 2015).

Pareja información cronológica nos ofrecen los 17 ungüentarios ${ }^{16}, 9$ de ellos globulares -Tipo A-IV.2.1- y los 8 restantes fusiformes -Tipo A-IV.2.2-, pues, si bien los segundos encuentran su mayor difusión en las necrópolis ibéricas entre los ss. III y II a. C., los primeros se distribuyeron por el SE ibérico fundamentalmente en contextos de finales del s. IV y todo el III a. C. (Sala, 1998: 36).

Las tanagras se generalizan por el SE peninsular a partir del s. III a. C., cuando a las importaciones más antiguas comienzan a sumárseles las primeras producciones de terracotas locales. Tradicionalmente, se ha mantenido que las terracotas importadas estarían llegando a la región ya en el s. IV a. C., pero esta fecha tan antigua se ha argumentado precisamente a partir de las piezas del depósito L127A de La Albufereta (Horn, 2011: 1163-1164), cuya cronología, como estamos viendo, no está nada clara. En cambio, hemos de observar que otras terracotas de fábrica e iconografía similar a las de L127 han aparecido en necrópolis cercanas formando parte de enterramientos datables en el s. III a. C. ${ }^{17}$. Y lo mismo sucede con los pebeteros con forma de cabeza femenina: en los últimos estudios, la importación y la producción local de estos objetos en el SE ibérico se datan a partir del s. III a. C., con la sola excepción del depósito L127 de La Albufereta, cuya cronología se asume en el s. IV a. C. por las cerámicas áticas

16 cs3074, 3077, 3078, 3079, 3080, 3081, 3084, 3085, 3086, 3087, 3089, 3090, 3094, 3095, 3616, 4804.

${ }_{17} C f$., por ejemplo, las de las sepulturas 341 y 343 de Cabecico del Tesoro (Sánchez Meseguer y Quesada, 1991: 353). 

y la memoria en la necrópolis de La Albufereta, Alicante, en el s. III a. C.

antes mencionadas (Pena, 2007: 25; Sala y Verdú, 2014: 31).

En L127A, en resumen, observamos que se acumulan materiales de muy diversa cronología: 3 recipientes áticos de finales del s. v a. C.; toda una serie de elementos pertenecientes a un carro que se podría datar en el s. IV a. C., y 17 ungüentarios, 7 tanagras antropomorfas y 3 pebeteros que podrían situarse en el s. III a. C.; además, claro está, de numerosos materiales más difícilmente fechables.

Por lo que respecta al resto de los depósitos incluidos bajo el túmulo L127, cuya relación estratigráfica con L127A no es, como ya dijimos, evidente, merece la pena destacar, además de dos nuevos pebeteros con forma de cabeza femenina, un gran pithos decorado ${ }^{18}$ empleado como urna cineraria en L127C que encuentra buenos paralelos en otros recipientes similares reutilizados como urnas en el Cigarralejo, en Mula, Murcia, en contextos del s. IV a. C. (Verdú, 2015: 182); tres fíbulas anulares hispánicas ${ }^{19}$ del tipo 6в de Argente datadas entre los ss. IV y III a. C. halladas en $\mathrm{L} 127 \mathrm{D}-\mathrm{y}$, por lo tanto, estratigráficamente posteriores al pithos que acabamos de mencionar-, y un guttus campaniense A -forma $8173 \mathrm{a}$ de Morel- ${ }^{20}$ de la segunda mitad del s. III a. C. (Horn, 2011: anexo I, 396), descubierto en L127F. La moneda gaditana con un delfín representado, de la que lamentablemente hemos perdido la pista, estaría hablándonos también de una cronología de entre los ss. III y i a. C. (Guadán, 1963).

Rubio (1986: 385) asumió que todos los materiales de la 'Gran Sepultura' concordaban con las importaciones áticas, por lo que insistió en que el conjunto L127 era uno de los más antiguos de la necrópolis. Es más, dio por sentado que todos los depósitos bajo el túmulo L127 conformaban un único conjunto cerrado. En cambio, no explicó las referencias que Lafuente y Belda hacen en sus escritos a la presencia de recipientes campanienses ni a la moneda gaditana, y, de hecho, consideró que el guttus campaniense era propio del s. IV a. C. (Rubio, 1986: 230).

\footnotetext{
$18 \quad \mathrm{Cs} 4988$.

$19 \operatorname{cs} 3678,5294$ y 5290.

$20 \quad \operatorname{cs} 3604$.
}

La propuesta de Verdú (2015: 82-83) parte de presupuestos más sólidos. Este considera que L127A pudo constituir, efectivamente, el depósito más antiguo de la necrópolis de La Albufereta, pero no lo cree un conjunto cerrado, sino más bien un ustrinum, una pira en la que se cremarían los cuerpos de los difuntos de un determinado grupo familiar a lo largo de varias generaciones, depositándose los restos resultantes, junto con ciertas ofrendas a los antepasados, en torno a la estructura. Incluso añade que junto a esta pudo haber existido un segundo ustrinum más pequeño, ya identificado como tal por Lafuente -L127E-, y que sería contemporáneo o posterior a L127A. Así las cosas, en su opinión, el conjunto L127 habría comenzado a emplearse a finales del s. va. C. y se amortizaría definitivamente entre finales del III y comienzos del II a. C.

Dejando a un lado por el momento la funcionalidad del conjunto, baste señalar que esta lectura parte de la consideración, coherente con los postulados procesuales, de que la cronología de cada objeto coincide con la fecha de su amortización, $y$, por lo tanto, su yuxtaposición marca el intervalo temporal a lo largo del cual la estructura en la que se depositaron se mantuvo en uso. Se trata de una interpretación que, con la información de la que disponemos, no es posible refutar. El modelo teórico propuesto es similar al planteado en su momento para el depósito votivo de El Amarejo (Bonete, Albacete), una fosa en la que se suponía que los habitantes del lugar habrían cremado periódicamente sus ofrendas entre comienzos del s. IV y finales del III o comienzos del II a. C. (Broncano, 1989). Obsérvese la coincidencia en el ritual y la cronología. Sin embargo, un estudio detallado de los materiales y la estratigrafía del depósito del Amarejo permitió hace unos años constatar que todo el conjunto votivo había sido amortizado de una sola vez, independientemente de la heterogénea cronología de sus componentes (Blánquez, 1996: 158-159). Por desgracia, la ausencia de estratigrafía en L127 impide efectuar una comprobación similar.

Ahora bien, en las siguientes páginas nos atrevemos a proponer para L127A una lectura alternativa. Si dejamos abierta la posibilidad de que algunos de 
los artefactos documentados en el depósito se pudieron mantener en circulación durante un período de tiempo largo antes de ser amortizados, tendríamos que considerar de nuevo la hipótesis de que el conjunto L127A fuera un conjunto cerrado, creado de una sola vez en la segunda mitad del s. III a. C. Así parece sugerirlo, como más adelante veremos, la coherencia temática, casi diríamos que sintáctica -funeraria, política, acaso mistérica- entre sus diferentes componentes, pese a sus cronologías tan dispares. La hipótesis, en definitiva, de que un conjunto de objetos de cronología heterogénea fueran entregados a las llamas de una sola vez en la segunda mitad del s. III a. C. -cronología de sus materiales más recientes-, y que poco después se distribuyeran en torno a las cenizas de la hoguera ritual toda una serie de depósitos, ofrendas y tumbas, se nos presenta, en el momento actual, como sumamente verosímil.

\section{El conjunto L127A: ¿sepultura, silicernium, ustrinum o depósito ritual?}

Se ha aceptado tradicionalmente que todas las estructuras agrupadas bajo el túmulo L127 constituían enterramientos, relacionados entre sí quizás por los lazos familiares de los difuntos allí sepultados (cf., por ejemplo, Rubio, 1986: 214-232; Olmos, 2007: 377-388). La denominación que desde un primer momento se empleó para la hoguera central del conjunto, la 'Gran Sepultura' (Lafuente, 1934: 22-24), discurre en este sentido.

Sin embargo, durante la excavación de esta 'Gran Sepultura' -L127A- no se documentaron restos óseos, que tampoco se mencionan en los distintos recuentos asociados a la llamada 'Hoguera ritual' -L127F- ni en el 'ustrinum' - L127E- superpuesto a esta ni tampoco en la hoguera cuadrada aledaña -L127B- (Lafuente, 1934; Belda, 1934; 1947: 245). Sí se documentaron, por el contrario, en la 'Hoguera de cremación' -L127c-, en las tumbas gemelas superpuestas a esta $-\mathrm{L} 127 \mathrm{D}-\mathrm{y}$ en los cinco enterramientos instalados en torno a la 'Gran Sepultura' (Lafuente, 1934: 22-24). En muchos casos,

Ediciones Universidad de Salamanca / @ه্త los huesos se hallaban recogidos dentro de urnas cinerarias.

El dato, aunque no es concluyente debido a las carencias de la metodología arqueológica de la época, sí es al menos significativo. Máxime cuando Figueras (1952b: 182-184), mucho más exhaustivo en sus publicaciones que Lafuente o Belda, sostiene que todas las tumbas que él excavó en La Albufereta contenían restos humanos, pero que también había en la necrópolis hogueras y acumulaciones de cenizas destinadas a 'ceremonias y ritos especiales' que no cabía identificar con tumbas (Figueras, 1956: 1213). Por su parte, Belda reconoce en sus escritos la existencia de algunas hogueras desperdigadas por el cementerio, consistentes en bolsadas de ceniza con fragmentos cerámicos (Belda, 1947: 244). Respecto a L127, de hecho, Belda (1947: 245) señaló que sus características se apartaban de manera significativa de todos los demás conjuntos de la necrópolis, en razón de lo cual no cabía interpretar, pensaba él, el conjunto como una tumba propiamente dicha, sino como un silicernium, esto es, una hoguera a la que se arrojarían los restos de un gran banquete funerario (Belda, 1947: 245). No obstante, y al margen de la problemática que la presencia de silicernia en las necrópolis ibéricas acarrea en sí misma (García Cardiel, 2011), nada en el registro de L127A nos permite aceptar tampoco tal interpretación.

Recientemente, Verdú (2015: 83) ha apuntado que L127A pudo tratarse más bien de un ustrinum. Ello explicaría, según el investigador, la heterogeneidad cronológica de los objetos encontrados en la hoguera, la ausencia de huesos, la acumulación de cenizas y la presencia del hornillo de adobe, que podría haberse empleado para avivar la llama del quemadero. Ahora bien, por lo que sabemos de los rituales funerarios ibéricos, y las sepulturas de $\mathrm{La}$ Albufereta así lo atestiguan, la recogida de los restos óseos de la pira con vistas a su traslado a la sepultura definitiva solía ser muy selectiva, se llevaba a cabo aún en caliente y, por lo tanto, en la hoguera solía quedar abandonada una gran cantidad de restos humanos, que en L127A, sin embargo, no aparecen. También se solía recoger en estos ustrina el ajuar funerario incinerado junto al difunto y que debía

Zephyrus, LXXXVIII, julio-diciembre 2021, 111-134 
acompañar a este a la tumba; pero en la Gran Sepultura quedaron amortizados kýlikes enteras, numerosos ungüentarios y nada menos que los elementos metálicos de un carro. Nada tiene que ver este supuesto ustrinum, por ejemplo, con los ustrina bien conocidos de Castellones de Ceal (Jaén), empleados para una sola cremación y luego amortizados (Chapa et al., 1998). Ni tampoco con el de Hacienda Botella (Elche, Alicante), un ustrinum datable precisamente a finales del s. III a. C. en el que sí aparecieron los restos óseos del individuo cremado, y que fue amortizado por completo tras su uso puntual (Sala y Verdú, 2014: 27-28).

Todo ello parece apuntar en la dirección de considerar que $\mathrm{L}$ 127A fue una hoguera en la que en cierto momento de la segunda mitad del s. III a. C. se cremaron numerosos objetos de procedencias y cronologías diversas - pero no necesariamente ningún difunto, ni los restos de ningún banquete-, en un gesto que, dada la llamativa selección de los materiales y su singular estado de conservación, puede calificarse de ritual. La cronología dispar de los objetos amortizados, de hecho, no debe asombrarnos, pues no pocas sepulturas de la necrópolis evidencian asimismo la inclusión de auténticas 'reliquias' entre los objetos de su ajuar funerario (García Cardiel, 2017). En torno a las cenizas de esta gran hoguera, en fin, no tardarían en florecer toda una serie de sepulturas y nuevos depósitos.

\section{El carácter funerario del conjunto L127}

El carácter funerario del depósito L127A parece claro, no solamente por su localización en el centro de la necrópolis y por compartir túmulo con un gran número de sepulturas, sino también porque el simbolismo de sus materiales así parece corroborarlo.

No ofrecen dudas a este respecto las granadas, tanto la pequeña granada de arcilla conservada en el museo como el vaso plástico con forma de granada mencionado por Belda. El simbolismo de la granada, un fruto ligado con el Más Allá en buena parte del Mediterráneo, era bien conocido, y con parejas connotaciones, también en el mundo ibérico, como demuestran sus abundantes representaciones en esculturas, relieves y vasos plásticos hallados en necrópolis (Mata et al., 2010a; 2010b: 56-67), así como en varias escenas de ultratumba figuradas en los vasos de Sant Miquel de Llíria (Valencia) (García Cardiel, 2021: 54).

Pero detengámonos un momento en las tanagras del depósito L127A (Olmos, 2007: 377-388; Olmos y Tortosa, 2010: 250-251; Horn, 2011: 246-247; Verdú, 2011; 2015: 228-246) (Fig. 5). Entre ellas se cuenta un ejemplar ${ }^{21}$ que representa a un personaje femenino entronizado que sostiene en su regazo a un niño, al que amamanta. La kourotrophia, un tema bastante frecuente en la iconografía ibérica del s. III a. C., se tiñe de nuevas connotaciones en un espacio necropolitano como este, dando lugar a un impactante juego de espejos, vida-muerte, sustento-desintegración, vehiculizado por la imponente figura femenina. Un juego de espejos en el que de hecho inciden otras dos, o quizás tres, tanagras de este conjunto de La Albufereta. En efecto, nos encontramos también con una figura femenina estante $^{22}$, muy mal conservada, que parece vestir un largo manto y se toca con un amplio velo, y en cuyo brazo izquierdo sostiene a un niño contra su seno. La mirada de la mujer, desviada nuevamente hacia abajo y hacia la izquierda, nos revela la presencia del infante, del que, sin embargo, apenas se vislumbra una mano apoyada sobre el cuello de la madre. Análogo mensaje transmite una tercera pieza ${ }^{23}$, en la que el personaje femenino, que porta en su mano derecha una pequeña ave, muestra un avanzado estado de gravidez. Por último, un cuarto ejemplar ${ }^{24}$, muy fragmentario, nos muestra a una mujer estante que exhibe un polos sobre la cabeza, y sobre cuyo pecho izquierdo una tenue y desgastada protuberancia podría revelar una vez más la presencia de un infante no conservado, tal y como supo apreciar Verdú (2015: 238-239).

Las cuatro tanagras hacen hincapié, mediante la yuxtaposición de versiones sobre un mismo tema,

\footnotetext{
$21 \quad \operatorname{cs} 3710$.

$22 \operatorname{cs} 3100$.

23 cs3096.

24 Cs3061.
} 

y la memoria en la necrópolis de La Albufereta, Alicante, en el s. III a. C.

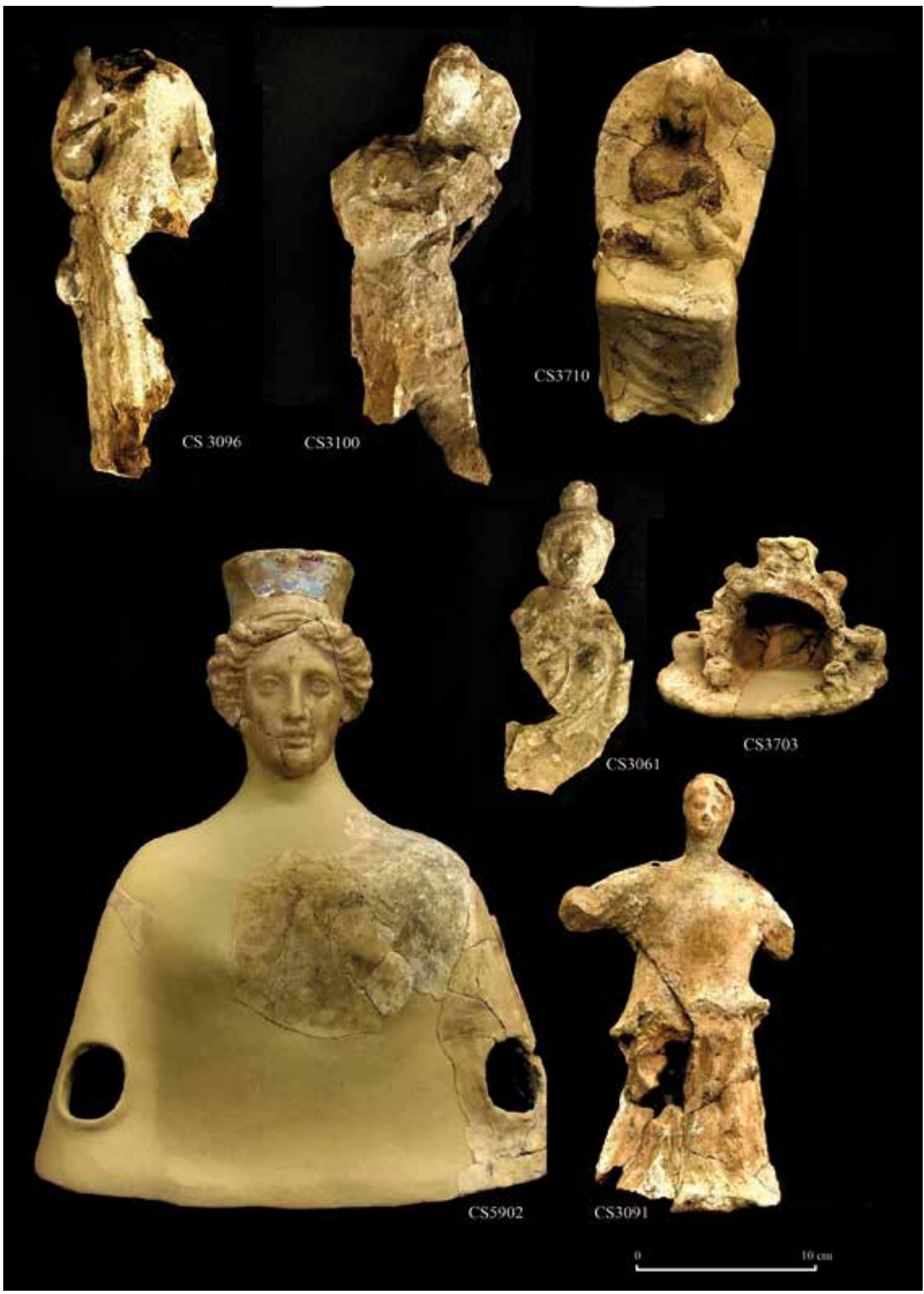

FIG. 5. Tanagras y otras terracotas del conjunto L127 de la necrópolis de La Albufereta; piezas conservadas en el MARQ. 
en el carácter protector y nutricio de la divinidad femenina, que no solo brinda sus atenciones a sus individuos escogidos en vida de estos -como en la contemporánea terracota de la Habitación F1 de La Serreta (Grau et al., 2008: 21)-, sino también en el momento de su muerte. A fin de cuentas, la deidad femenina favorece el tránsito de sus devotos entre esta existencia y la siguiente, como se pone de manifiesto, por ejemplo, en la esfinge del Parque Infantil de Tráfico de Elche (Alicante), El Monastil (Elda, Alicante), Pino Hermoso (Orihuela, Alicante), Poblado, y en un par de vasos de Sant Miquel de Llíria (García Cardiel, 2021). Un tema al que quizás se aluda también en las decoraciones de las dos kýlikes conservadas, al menos desde la perspectiva de sus propietarios ibéricos ${ }^{25}$.

En el medallón central de cs3639 (Fig. 6), una mujer enarbola en su mano derecha una corona vegetal entresacada del manojo que porta en la otra mano, y se la ofrece a un joven, desnudo salvo por un sucinto manto que no oculta su sexo. El joven se inclina respetuosamente y tiende ambas manos para recibir su regalo, apoyándose en la base de una columna truncada, posible metonimia de una palestra. Desde la óptica griega, probablemente se trate de un atleta recibiendo los laureles de la victoria, pero, en el imaginario ibérico, en el que no existen los gimnasios y la representación femenina suele acompañar a los viajes psicopompos, seguramente la escena podría interpretarse como la recepción que la diosa dispensa al difunto que está a punto de acceder al Más Allá. Se 'conmemora un tránsito', como advertía Olmos (2007: 379), pero la copa ya no habla del paso de un estatus ciudadano a otro, como originalmente lo hacía en el taller ático en el que se fabricó, sino que, en su nuevo contexto necropolitano, glosa el viaje entre este mundo y el ultraterreno. Y, en ella, el peso de la acción, en este caso la iniciativa de sancionar el viaje, recae sobre el personaje femenino, circunstancia que igualmente concordaría a la perfección con el imaginario ibero (Cabrera y Moreno, 2019: 117), tema en el que

25 Como ya apuntara en su momento, aunque sin desarrollarlo, R. Olmos (2000-2001: 361-363; 2007: 379-380). posiblemente insisten también las dos escenas de la superficie exterior del vaso, en las que un varón con manto dialoga con otros dos hombres desnudos pero adornados con coronas vegetales. La escena supone una variación del tradicional esquema de la iconografía griega, en el que un varón maduro instruye a dos jóvenes, pues en este caso la diferencia de edad no es evidente: el individuo con manto no lleva bastón ni barba y no se adorna con corona alguna, a diferencia de los jóvenes desnudos, que sí la portan. Quizás porque el sujeto del manto aún se halla en tránsito, todavía no ha sido heroizado por la diosa, que lo aguarda en el medallón de la kýlix para ofrecerle su preciado obsequio.

Un mensaje análogo podría desprenderse de la iconografía de la otra kýlix (Fig. 7). En el medallón, una mujer tocada con una corona radiada extiende una copa hacia su acompañante. Este, un varón, se encuentra sentado sobre una roca, asiento que resulta coherente con sus vestimentas, típicas de un viajero o cazador: coturnos, un manto sencillo recogido al hombro mediante fíbula anular y un haz de jabalinas. Únicamente destaca su tocado, una corona vegetal. Parece que el recién llegado al Más Allá coronado en la otra kýlix descansa ahora tras su largo viaje, mientras la diosa le ofrece un trago. Como en el mito griego ${ }^{26}$, bastará con que cualquier alimento traspase sus labios para que su destino quede sellado. El tema se repite con ligeras variaciones en las dos escenas exteriores del vaso. En ellas, el viajero se encuentra en pie y con su mano derecha sostiene un casco, en tanto que la mujer de la corona radiada, que continúa ofreciéndole la copa, sujeta en su mano izquierda un oinokhóe. Aparece aquí también un tercer personaje, ausente en el medallón, que observa la escena con curiosidad, manteniéndose algo al margen: un varón barbado, tocado también con la corona vegetal, cubierto por un manto sostenido en torno a las caderas y el antebrazo izquierdo, y apoyado en un bastón. A diferencia del recién llegado, el anciano va descalzo. Él no necesita coturnos, pues ya es un habitante del Más Allá. Un Más Allá esquivo, cuyo

26 H. Cer. 370-374. 
y la memoria en la necrópolis de La Albufereta, Alicante, en el s. III a. C.

umbral, quizás, aparece representado a sus espaldas en una de las caras exteriores, pero no en la otra.

Y es que el camino hacia el Más Allá no era sencillo. Estaba poblado de fieras, como las que, esculpidas en piedra, habían protegido desde antiguo las necrópolis ibéricas o como las que en nuestro depósito L127A rondan por la tapa de la lékane, en la que se alternan panteras, esfinges y leones (Olmos, 2007: 377-388). Hablamos de un no-espacio liminal, el territorio propio de los héroes, héroes como el que aparece en el medallón de bronce con incrustación de pasta vítrea del depósito L127. Un territorio ajeno al cotidiano, en fin, que en el SE ibérico de los ss. v y IV a. C. los difuntos agraciados con el favor de la diosa debían recorrer a caballo, pero en el que a partir del s. III a. C. comenzarán a aparecer también menciones a la presencia de carros (García Cardiel, 2014: 180-182). El viejo símbolo del carro
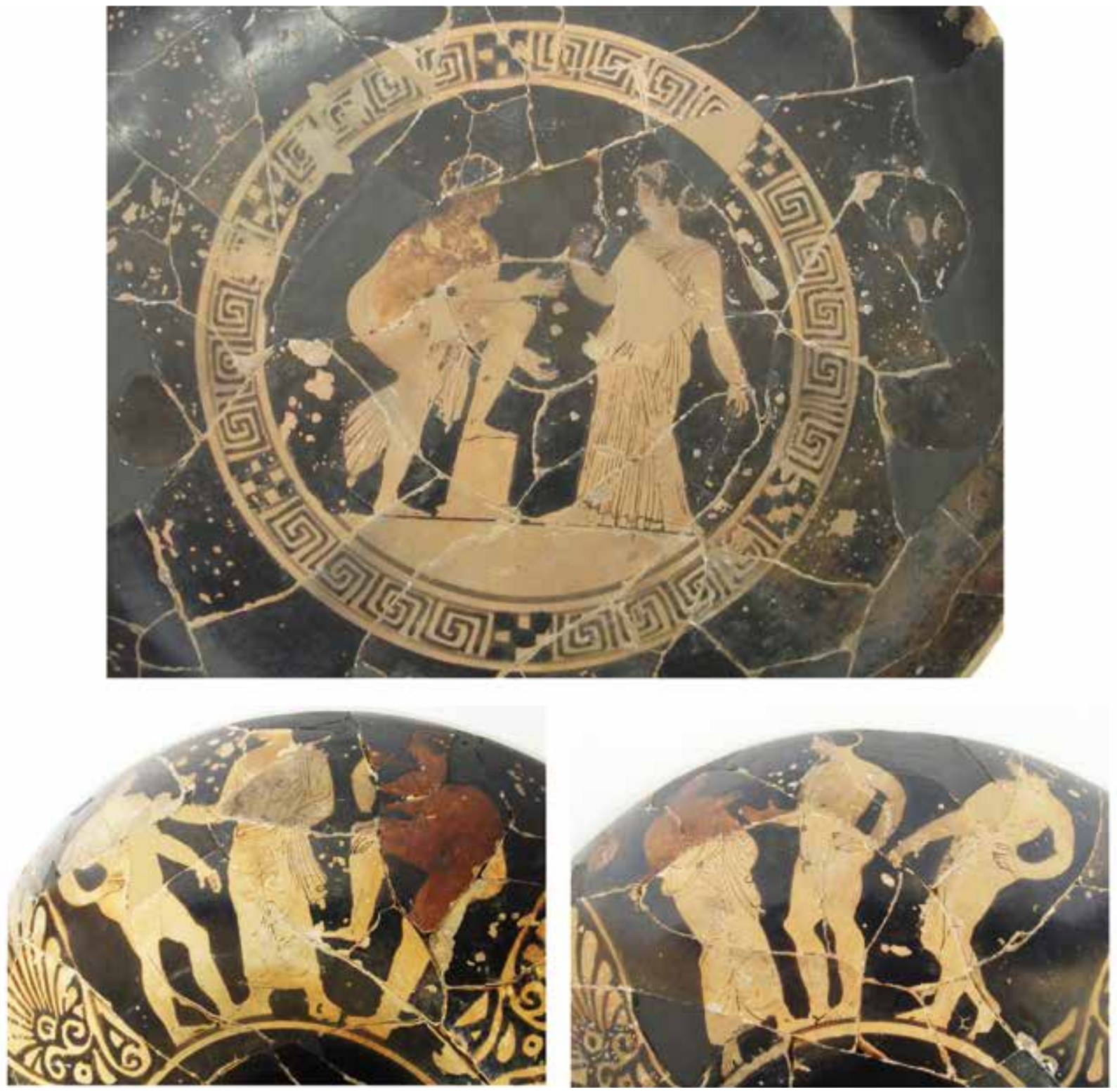

FIG. 6. Decoraciones de la kýlix CS3639; pieza conservada en el MARQ. 

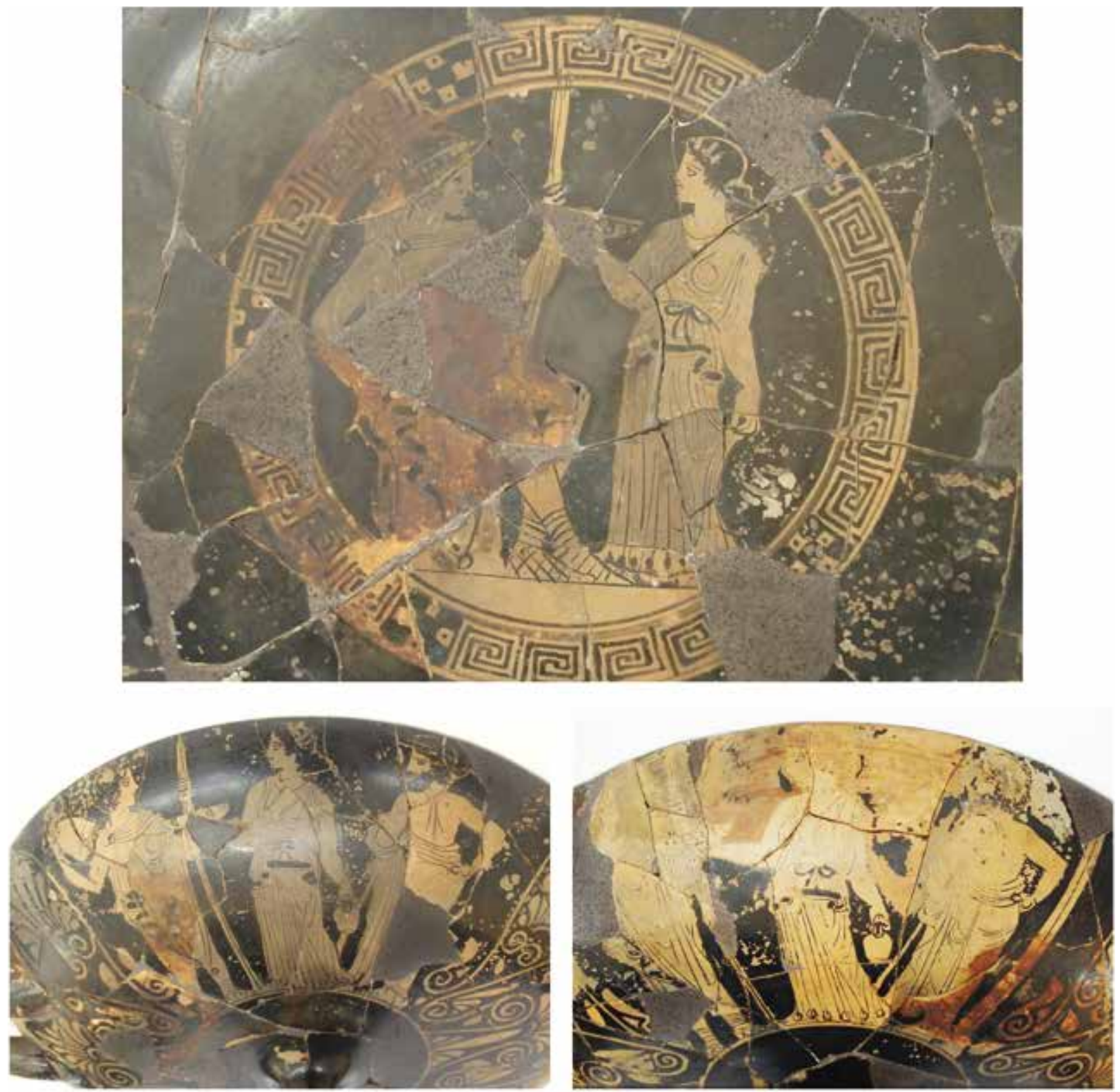

Fig. 7. Decoraciones de la kýlix CS6063; pieza conservada en el MARQ.

heroizador (Fernández Miranda y Olmos, 1986) se recupera en esta fase tardía del imaginario ibérico, de la mano quizás de unos aristócratas cuyos caballos comienzan a no aportarles ya, por sí mismos, la tan ansiada distinción ${ }^{27}$.

27 Cf. Quesada, 1997, para la aparición en el mundo ibérico a partir de finales del s. III a. C. de unos cuerpos de caballería que sobrepasarían los límites de las elites sociales.

\section{El posible carácter mistérico del conjunto} L127

Todavía no hemos hablado de una tanagra que nos invita a ensayar otro nivel de lectura para el depósito $\mathrm{L} 127 \mathrm{~A}$, más allá de la meramente funeraria. $\mathrm{Y}$ es que el discurso escatológico del que venimos hablando se complementa con toda una serie de 
matices, indicios y signos menos evidentes para los que quizás cabría proponer una posible interpretación mistérica.

Nos referimos a una pieza muy fragmentada ${ }^{28}$ en la que un varón transporta en volandas a un segundo personaje, en un esquema compositivo que ha sido identificado como una representación del rapto de Perséfone ${ }^{29}$ (Olmos, 2007: 385-386; Verdú, 2015: 238). La escena, sin paralelos en la iconografía ibérica prerromana, podría estar dialogando en el depósito L127A con la representación de la granada, la fruta que encadenó a Perséfone al Inframundo ${ }^{30}$, o incluso con el carro, en el que según el mito griego fue raptada la diosa ${ }^{31}$. A fin de cuentas, no olvidemos que la efigie de la diosa ibérica de los cereales se multiplica en los pebeteros de terracota, tanto en la 'Gran Sepultura' como en los depósitos amortizados en torno a ella.

Detengámonos un momento en los pebeteros. De todos los ejemplares mencionados en los recuentos de Lafuente y Belda, solo conservamos seis (Moratalla y Verdú, 2007: 343; Sala y Verdú, 2014: 31; Verdú, 2015: 257). Los tres procedentes del depósito $\mathrm{L} 127 \mathrm{~A}^{32}$ y los dos relacionados con los enterramientos horadados sobre el túmulo ${ }^{33}$ resultan bastante similares entre sí y pueden encuadrarse en el Tipo I de Pena, datable generalmente en el s. III a. C. Algo distinto es el ejemplar hallado en la hoguera L127c, pues podría corresponderse con el Tipo II de Pena o quizás situarse a medio camino entre este y el Tipo I; se trata, en todo caso, de un ejemplar probablemente importado que Horn (2011: anexo I, 541) fecha algo antes que los anteriores, en la transición entre el s. IV y el III a. C. Hablamos, en definitiva, de unos artefactos creados en el ámbito púnico centromediterráneo y difundidos por el SE ibero a partir del s. III a. C., seguramente ya desprovistos de su función originaria de quemaperfumes, pues en Iberia se concebían como meras imágenes

\footnotetext{
$28 \quad$ cs3097.

H. Cer. 19-22.

H. Cer. 372.

H. Cer. 17-18, 375-382.

c3093, 3141 y 3142 .

cs3092 y 3143 .
}

de la deidad a la que se ofrendaban (Pena, 2007: 28-29; Horn, 2011: 51-53; García Cardiel, 2015). Una deidad que los iberos concebirían sin duda como propia, pero que los griegos no tendrían problemas en reconocer como Démeter o Perséfone, y en la que los púnicos, quizás, verían a Tánit (Pena, 1987: 354). De cualquier manera, se trata de una diosa que se aparece, que brota espontáneamente del suelo, que controla la fertilidad de la tierra y que es capaz de trascender a voluntad entre este mundo y el otro (Olmos, 1996: 9-11).

La asociación de imágenes presente en el depósito L127 de La Albufereta podría esconder, creemos, algunos indicios alusivos a un culto con un cierto componente mistérico. Hablamos, lo acabamos de señalar, de una diosa de la fecundidad vegetal, relacionada con el tránsito entre este mundo y el siguiente. Una diosa cuya imagen aparece relacionada en L127A con las cuevas; en concreto, a través de una terracota en la que se representaba la entrada de una caverna rodeada de protuberancias cilíndricas horadadas que quizás sirvieran para insertar ramitas, flores o espigas (Lafuente, 1959: 40), o puede que simbolizaran depósitos de ofrendas en torno al espacio sacro (Olmos, 2007: 381). Una diosa cuyo culto entrañaría el uso de artefactos singulares y de función no aparente, como el vaso doble, y de grandes cantidades de perfumes -no olvidemos los nada menos que 17 ungüentarios conservados-. Por último, sabemos que en los ritos mistéricos la exhibición de ciertas imágenes, la interacción con ellas y la explicación de los mitos a los que aquellas aludían comportaban una parte esencial de la iniciación (Muñiz, 2008: 65-68). Puede que la acumulación de tanagras en el depósito L127A pueda interpretarse en este sentido. Y puede que, en concreto, esta aproximación arroje una nueva luz sobre una de las terracotas de las que aún no hemos hablado, un busto femenino, sin paralelos en la Península Ibérica, pero sí en Ibiza y en el mundo púnico centromediterráneo (Bisi, 1973: 74), de dimensiones casi naturales, con una cabeza comparativamente pequeña, pero casi idéntica a la de los pebeteros, también tocada con un cálatos, y en cuyos laterales dos orificios servirían para engarzar sendos 
brazos articulados ${ }^{34}$. Al parecer, esta imagen de la diosa, una verdadera proyección de los pebeteros, gesticularía e interactuaría con los participantes en el rito, convenientemente manipulada por uno de los oficiantes.

Un rito, este, del que quizás las kýlikes conservadas nos ofrezcan también nuevos datos. Recordemos que estas representaban a una deidad coronando a sus elegidos, léase, quizás, iniciados; una diosa de corona radiada - "Démeter, la bien coronada", la denomina el himno homérico (H. Cer. 224, 307, 385,470 - que ofrecía un preciado líquido a quienes a ella se acercaban.

Los iniciados en los ritos mistéricos, en última instancia, ansiaban una existencia mejor en el Más Allá, facilitada por una diosa que podía proporcionársela. Una diosa que, al menos en el mito griego, hace gala de su poder incluso para conceder la vida eterna a sus elegidos, criándolos a sus pechos y, por las noches, depositándolos en medio de las llamas ${ }^{35}$. En una hoguera como la que, en mitad de la necrópolis de La Albufereta, acogió en un momento dado todas estas imágenes y objetos.

Pero quizás estemos haciendo demasiado hincapié en la Démeter eleusina. No perdamos de vista que hablamos de un culto practicado en época helenística en los límites de la Eschatiá. Algunas de las imágenes que tomaron parte en él eran griegas y otras eran púnicas, pero también se emplearon artefactos ibéricos, y difícilmente podremos llegar a saber cómo denominarían a la deidad los participantes en el culto. Al fin y al cabo, las divinidades mistéricas confluyeron muy pronto en su camino hacia el henoteísmo, dotándose de atributos muy similares y llegando a solaparse o incluso a confundirse (Turcan, 2007). La identificación entre Démeter e Isis que ya se vislumbraba en Heródoto, para Plutarco, es directa ${ }^{36}$. Como señala el Primer Himno de Isidoro, datable en el s. I a. C. pero con reminiscencias bastante más antiguas (Muñiz, 2008: 115), y ciertamente útil para profundizar en

\footnotetext{
$34 \quad$ Cs5902.

35 H. Cer. 233-234.

36 Hdt. 2, 171, 2-3; Plut., Is. 361 E.
}

las connotaciones del culto mistérico a Isis en época helenística (Sfameni, 2007):

... Todos los mortales que habitan la tierra infinita -tracios, griegos y cuantos bárbaros existenexclaman tu maravilloso nombre, muy honrado por todos, pero cada uno en su propia lengua, en su país. Los sirios te llaman Astarté, Ártemis, Nanea; las tribus licias te llaman Leto, la seńora; los tracios te llaman también Madre de los dioses; y los griegos te llaman Hera la del Gran Trono, Afrodita, buena Hestia, Rea y Démeter... (Himno de Isidoro, 1, 14-22)

La figura de Isis, de hecho, tuvo un enorme y temprano éxito por todo el Mediterráneo oriental y central, pero su presencia no está atestiguada explícitamente en la Península Ibérica hasta el desembarco de las legiones romanas (Uroz, 2004-2005: 166-169). Ahora bien, ¿no podría haber llegado su culto ya de la mano de los cartagineses? ¿Sobre todo en un puerto como el de La Albufereta, políticamente vinculado al proyecto imperialista cartaginés $^{37}$, y en un ambiente tan multicultural como el que se habría generado en aquel enclave? ¿No se declaraba la propia diosa un canal de comunicación entre culturas al proclamarse responsable de la invención de todas las lenguas, tanto la griega como las de los bárbaros? ${ }^{38}$. ¿Y acaso no encontramos en el depósito L127 de La Albufereta cierta ambigüedad entre Démeter e Isis? A fin de cuentas, como Démeter, Isis también se preciaba de haber regalado el cereal a los seres humanos y de hacerlo germinar cada año ${ }^{39} ; \mathrm{y}$, como Démeter, Isis se vinculaba al mundo de la Ultratumba, habiendo usurpado ya en época helenística las cualidades salvíficas de su esposo (Bianchi, 1980). Para la iniciación en sus misterios, sostiene Apuleyo, era necesario "aproximarse a las fronteras de la muerte" 40 .

Pero Isis era también una diosa sanadora, especialista en los problemas oftálmicos (Muñiz, 2008: 107). En su santuario de Delos, por ejemplo, se le

37 Para la relación entre Isis y el poder imperial, $c f$. Bricaul y Versluys, 2011.

38 Himno de Cime, 31.

39 Himno de Cime, 7; Himno de Salónica, 1; Diod. 1, $27,4$.

40 Apul., El asno de oro 11. 23. 6. 
solían ofrendar ojos de plata (Prêtre, 1999: 390). Circunstancia que, evidentemente, nos obliga a volver sobre una de las piezas de nuestro depósito L127A, el ojo de terracota. Se trata de una imagen muy esquemática, que difícilmente se puede interpretar como un uadjet egipcio, pese a lo que en muchas ocasiones se ha dado por sentado (Lafuente, 1934: 39; Figueras, 1947: 222). De hecho, si observamos con detenimiento la pieza, repararemos en que en realidad es un recorte de una terracota mayor, con toda probabilidad de un rostro humano (Verdú, 2015: 276). En los yacimientos ibéricos del SE no son raros, sobre todo en el s. III a. C., este tipo de recortes de imágenes sobre cerámica o terracota (Olmos, 1999: 434); recortes toscos, si se quiere, pero que cumplen su función de subrayar la imagen que contienen, recontextualizándola y resemantizándola.

Isis, en fin, era la patrona de la navegación y de los vientos (Muñiz, 2012). Circunstancia que quizás nos permita comprender mejor la única de las tanagras de la que aún no hemos hablado: una mujer de amplio torso cuya mirada se dirige hacia abajo; cuyos brazos, abiertos, no se han conservado, y cuya falda vaporosa se arremolina en varios pliegues, como si el viento estuviera a punto de levantarla ${ }^{41}$. Dos pequeños orificios circulares horadan sus hombros, atravesando la pieza de parte a parte, por encima de otros dos huecos más grandes, rectangulares, que se abrieron solo en la parte posterior. Nos encontramos con toda probabilidad ante una Niké alada -cuyas alas, postizas, no se han conservado- que ha sido representada en el momento de posar sus pies en el suelo (Olmos, 2007: 382-383), como la Victoria de Samotracia o como una terracota de comienzos del s. II a. C. hallada en Lemnos $^{42}$. Parece diseñada para exhibirse colgando por los hombros, por lo que con ella vuelve a entrar en juego el componente experiencial, performativo, del rito. En el contexto del depósito alicantino, la efigie alada pudo ser empleada en alusión a una deidad que dominaba los vientos, que, desde la óptica mediterránea, quizás se denominara Isis, o puede

$41 \quad$ Cs3091.

42 Museo de Louvre-Lens, n..$^{\circ}$ inv. Myrina, 42. que Tanit, a la que siempre se representaba alada, pero que desde la perspectiva ibérica sin duda resultaría fácilmente asimilable a la diosa con alas que, por ejemplo, aparece guiando la cabalgata hacia el Más Allá de la esfinge del Parque Infantil de Tráfico de Elche (Chapa y Belén, 2011), y que a partir del s. II a. C. se convertiría en protagonista de las decoraciones vasculares ilicitanas.

$\mathrm{Y}$ es que de lo que estamos hablando, recordémoslo, es de un middle ground colonial. Si es que a La Albufereta llegó el culto a Démeter-Isis, o al menos algunos de los elementos de dicho culto, lo hizo de la mano de los cartagineses que apoyaron activamente a las elites locales del enclave. Unos cartagineses cuya diosa Tanit, por cierto, había asumido muchas de las atribuciones de las otras dos deidades. Acaso no sea casual que, en las propias proximidades de La Albufereta, apareciera una mención epigráfica altoimperial a la restauración de un templo consagrado a la diosa Juno ${ }^{43}$; diosa que, en su advocación de Juno Caelestis, sirvió a los romanos para asimilar a la Tanit púnica, tanto en el norte de África como en el SE peninsular.

\section{Interpretación en clave política del conjunto L127}

En resumidas cuentas, lo que proponemos es que, en la segunda mitad del s. III a. C., y por lo tanto coincidiendo con un período de grandes transformaciones que convulsionaron la zona, un individuo o un grupo de individuos ejecutó en el cementerio de La Albufereta un complejo ritual, que incluyó la cremación de toda una serie de objetos cuidadosamente seleccionados, en la mayor parte de los cuales el impacto térmico es claramente perceptible.

A lo largo del acontecimiento, se amortizaron artefactos de gran valor y exotismo. Quienquiera que fuera el responsable del acto pudo desprenderse de una gran cantidad de riquezas y estaba en disposición de acceder a los mejores mercados mediterráneos. Si es una circunstancia bien conocida que

43 CIL II, 3557. 
el acceso a la información y los mercados lejanos otorga prestigio a quien lo ostenta (Helms, 1988), el ordenante de este ritual hubo de ser uno de los personajes más preeminentes de su comunidad, bien conectado además con los agentes coloniales púnicos.

El evento, de hecho, parece redundar en este acercamiento entre las estructuras culturales locales y las cartaginesas. La amortización de preciados objetos de un gran simbolismo en una hoguera encendida en una necrópolis no es precisamente un gesto ritual infrecuente en el mundo ibérico, y casi ninguno de los materiales que se amortizaron en L127 resultaría totalmente extraño en los cementerios ibéricos. El discurso escatológico en el que insisten la mayor parte de estos artefactos e imágenes, alusivos a un viaje al Más Allá lleno de dificultades, relacionado con un carro y con la asistencia de una deidad femenina, era bien conocido en el mundo ibérico del SE. Pero ya hemos señalado que, al menos en nuestra opinión, este mensaje se complementaba en La Albufereta con toda una serie de elementos fuertemente influidos por los cultos mistéricos mediterráneos; unos elementos que solo resultarían comprensibles, quizás, para ciertos iniciados.

Ahora bien, el comanditario de la celebración que se desarrolló en La Albufereta no solo se presentó como 'señor del espacio', intermediario entre su comunidad y el resto del mundo mediterráneo; también se arrogó la cualidad de 'señor del tiempo', depositario de la tradición y descendiente de un antiguo linaje. Por ello no dudó en amortizar en la hoguera los elementos de un carro que probablemente tendría ya por entonces más de un siglo de antigüedad y también un juego de importaciones griegas de más de doscientos años. El pasado prestigia, y su instrumentalización a través de las reliquias resulta extraordinariamente eficaz a la hora de movilizar el capital simbólico (Lowenthal, 1998). El poder requiere de un pasado que lo legitime, de un recuerdo fundante que congele la historia para naturalizar el presente; $y$, cada vez que ese poder cambia o se modifican sus presupuestos, ha de dotarse de nuevos 'recuerdos' que modelen la memoria social comunitaria (Assmann, 2011: 68-70).
En efecto, ya vimos que el enclave de La Albufereta llevaba concibiéndose como un espacio sacro desde épocas muy antiguas, como se desprende de las esculturas allí descubiertas, y es posible que desde comienzos del s. Iv a. C. viniera siendo utilizado también como lugar de enterramiento, primero por los habitantes del Tossal de les Basses y después por los del Tossal de Manises. El cementerio era sin duda uno de los puntos nodales más importantes del paisaje sagrado comarcal, toda una referencia a la hora de construir la identidad comunitaria local. Así lo debieron de entender las elites que organizaron el ritual del que hablamos, poniendo en conexión su ceremonia con la tradición y las estructuras culturales de la comunidad. Puede que incluso este se oficiara en conexión con algún enterramiento previo. No olvidemos que a unos dos metros de L127A se encontraba el conjunto compuesto por la superposición de las sepulturas $\mathrm{L} 127 \mathrm{D}$ sobre la sepultura $\mathrm{L} 127 \mathrm{C}$, datables las tres, sin poder precisar más, entre los ss. IV y III a. C. y, por lo tanto, acaso anteriores a $\mathrm{L} 127 \mathrm{~A}$.

\section{Conclusiones}

A lo largo de estas páginas hemos propuesto que las estructuras amortizadas bajo el túmulo L127 de la necrópolis de La Albufereta podrían responder a un ritual oficiado a finales del s. III a. C. que, por lo que sabemos, constó cuando menos del encendido de una gran hoguera entre cuyas llamas se depositaron toda una serie de objetos, muchos de ellos especialmente onerosos y exóticos.

La llamada 'Gran Sepultura' -el depósito L127A- no era un enterramiento, aunque su carácter funerario está fuera de toda duda, y no solo por su localización en el centro de una necrópolis. Sus materiales y las imágenes que sobre estos aparecen, pese a su heterogeneidad, pueden ponerse en relación con el imaginario ibérico sobre el tránsito psicopompo. Ahora bien, hemos creído vislumbrar también en algunos de estos materiales ciertos indicios relacionables con los cultos mistéricos mediterráneos. Algunos atributos de Démeter, Isis, Tanit

Zephyrus, LXXXVIII, julio-diciembre 2021, 111-134 

y la memoria en la necrópolis de La Albufereta, Alicante, en el s. III a. C.

y los rituales iniciáticos a ellas debidos parecen adivinarse en elementos como las tanagras, la cueva o el ojo de arcilla. Y es que el evento celebrado en La Albufereta pudo tener diversos niveles de lectura, algunos más accesibles para toda la población local que participara en él o lo contemplara y otros más restringidos, que matizarían los anteriores significados a ojos de ciertos iniciados.

Lo que sí parece claro, en todo caso, es que el individuo, la familia o el grupo social responsable del ritual llevó a cabo toda una exhibición de su capacidad inversora. Sus impulsores se presentaron como los intermediarios entre su comunidad y los dioses, entre su comunidad y el mundo y entre su comunidad y el pasado. El evento, evidentemente, supuso un gran gasto, pero ha de ser puesto en relación con las rápidas transformaciones sociopolíticas que los habitantes del enclave experimentaron a finales del s. III a. C. En algún momento del último tercio de dicha centuria se fundó en el Tossal de Manises un nuevo asentamiento, cuyas elites parecen estar actuando en connivencia con el poder hegemónico cartaginés. Estas elites locales necesitaban de unos nuevos presupuestos ideológicos sobre los que fundamentar su nueva posición. Y los buscaron resemantizando el paisaje sagrado de la antigua necrópolis con un vistoso ritual que pretendía naturalizar la nueva situación, matizando la tradición escatológica ibérica precisamente para presentar como tradicional lo que no lo era tanto. Construyendo, mediante esta demostración, memoria, identidad y paisaje.

\section{Fuentes antiguas}

Apuleyo: El asno de oro. Traducción de Rubio, L. (1978). Madrid: Gredos.

Diodoro: Biblioteca histórica. Traducción de Parreu, F. (2001). Madrid: Gredos. H. Cer. $=c f$. Himnos homéricos.

Heródoto: Historias. Traducción de Schrader, C. (1977-1985). Madrid: Gredos.

Homero: Himnos homéricos. Traducción de Bernabé, A. (1978). Madrid: Gredos.

Isidoro: Himno de Cime $=c f$. Himnos a Isis.
Isidoro: Himno de Salónica = Himnos a Isis .

Plutarco: Obras morales y de costumbres (Moralia) VI. Isis y Osiris. Diálogos piticos. Traducción de Pordomingo, F. y Fernández Delgado, J. A. (1995). Madrid: Gredos.

vv. AA.: Himnos a Isis. Traducción y edición de Muñiz, E. (2006). Barcelona: Trotta.

\section{Bibliografía}

ALFÖLDY, G. (2003): “Administración, urbanización, instituciones, vida pública y orden social”. En AвAsCAL, J. M. у AвAD, L. (coords.): Las ciudades y los campos de Alicante en época romana. Canelobre, 48. Alicante, pp. 35-57.

Assman, J. (2011): Historia y mito en el mundo antiguo. Madrid: Gredos.

Beazley, J. D. (1963): Attic Red-Figure Vase-Painters. Oxford: Clarendon.

BELDA, J. (1947): "Algunos restos del antiguo culto a la diosa religioso-funeraria". En II Congreso Arqueológico del Sudeste Español. Albacete: Museo Arqueológico de Murcia, pp. 236-259.

Bianchi, U. (1980): "Iside dea misterica. Quando". En Perennitas. Studi in onore di A. Brelich. Roma: Ateneo, pp. 9-36.

Blánquez, J. J. (1996): "Lugares de culto en el mundo ibérico. Nuevas propuestas interpretativas de espacios singulares en el sureste meseteño", Revista de Estudios Ibéricos, 2, pp. 147-172.

Bricaul, L. y Versluys, M. J. (2011): "Isis and Empires". En Bricaul, L. y Versluys, M. J. (eds.): Power, Politics and the Cults of Isis. Leiden: Brill, pp. 3-35.

Broncano, S. (1989): El depósito votivo ibérico de El Amarejo (Bonete, Albacete). Madrid: Ministerio de Cultura.

Cabrera, P. y Moreno, M. (2019): "Vasos griegos e imágenes femeninas en el Sureste de la Península Ibérica”. En Tortosa, T. y Cabrera, P. (eds.): Encuentros con las imágenes femeninas de Iberia. Mérida: Mytra, pp. 93-126.

Castelo, R. (1995): Monumentos funerarios del Sureste peninsular: elementos y técnicas constructivas. Madrid: UAM.

Chapa, T. y Belén, M. (2011): "Viaje a la eternidad. El grupo escultórico del Parque Infantil de Tráfico (Elche, Alicante)", Spal, 20, pp. 151-174.

Zephyrus, LXXXVIII, julio-diciembre 2021, 111-134 

y la memoria en la necrópolis de La Albufereta, Alicante, en el s. III a. C.

Chapa, T.; Pereira, J.; Madrigal, A. y Mayoral, V. (1998): La necrópolis ibérica de Los Castellones de Ceal (Hinojares, Jaén). Jaén: Junta de Andalucía.

Fernández-Miranda, M. y Olmos, R. (1986): Las ruedas de Toya y el origen del carro en la Peninsula Ibérica. Madrid: Ministerio de Cultura.

Ferrer, C. (2005): "Asentamientos portuarios históricos del litoral meridional valenciano", Méditerranée, 104, pp. 119-128.

Figueras, F. (1936): "Arqueología levantina. Las excavaciones de Alicante", Anales del Centro de Cultura Valenciana, 9 (25), pp. 1-5.

Figueras, F. (1947): "Las excavaciones de Alicante y su trascendencia regional”. En II Congreso Arqueológicos del Sudeste Español. Albacete: Museo Arqueológico de Murcia, pp. 207-236.

Figueras, F. (1952a): "Los cartagineses en el iberismo del Sudeste”. En II Congreso Nacional de Arqueología. Zaragoza: Instit. Fernando el Católico, pp. 421-433.

Figueras, F. (1952b): "Esquema de la necrópolis cartaginesa de Alicante", Archivo de Prehistoria Levantina, 3, pp. 179-194.

Figueras, F. (1956): La necrópolis ibero-púnica de la Albufereta de Alicante. Valencia: Diput. Provincial.

Fletcher, D. (1957): “Toneles cerámicos ibéricos", $A r$ chivo de Prehistoria Levantina, 6, pp. 113-147.

Fletcher, D.; Pla, E. y Alcácer, J. (1965): La Bastida de les Alcusses (Mogente-Valencia). Valencia: sip.

García CANO, J. M. y GiL, F. (2009): La cerámica ática de figuras rojas: talleres y comercio (s. IV a. C.). Murcia: Univ. de Murcia.

García Cardiel, J. (2011): "Reflexiones en torno al banquete funerario ibérico”, ARYS, 9, pp. 119-153.

García Cardiel, J. (2014): "A lomos de la esfinge, guiados por la diosa: el tránsito al Más Allá en el imaginario ibérico". En Baglioni, I. (ed.): Sulle rive dell'Acheronte. Costruzione e percezione della sfera del Post Mortem nel Mediterraneo Antico 1. Roma: Quasar, pp. 171-184.

García Cardiel, J. (2015): "Pebeteros en la costa. Santuarios, peregrinaciones y rituales en la Contestania ibérica (ss. III-II a. C.)", Zephyrus, LXXvI, pp. 77-98.

García Cardiel, J. (2017): "Vasos griegos en la necrópolis de La Albufereta (Alicante): signos helenos para discursos contestanos". En Aquilué, X.; CAbrera, P. y Orfila, M. (eds.): Homenaje a Glòria Trias Rubiés. Cerámicas griegas en la Peninsula Ibérica: cincuenta años después (1967-2017). Gerona: Iberia Greca, pp. 213-220.
García CARDiel, J. (2021): "La última cabalgada: imaginarios del tránsito psicopompo ibérico". En Barroso, R. A. y Castillo, J. A. (eds.): Discurso, espacio y poder en las religiones antiguas. Oxford: Archaeopress, pp. 43-59.

García I Martín, J. M. (1996): "Una cratera de columnas de figures negres a la necrópolis de L'Albufereta d'Alacant (L'Alacantí)". En XXIII Congreso Nacional de Arqueología. Elche: Ayto. de Elche, pp. 473-480.

Grau, I.; Olmos, R. y Perea, A. (2008): "La habitación sagrada de la ciudad ibérica de La Serreta", Archivo Español de Arqueología, 81, pp. 5-29.

Guadán, A. M. (1963): Las monedas de Gades. Madrid: ANE.

Helms, M. W. (1988): Ulysses' sail. An ethnographic Odyssey of power, knowledge, and geographical distance. Princeton: PUP.

Horn, F. (2011): Ibères, grecs et puniques en Extreme Occident. Les terres cuites de l'espace ibérique du vIIt au II siècle av. J.-C. Madrid: Casa de Velázquez.

Lafuente, J. (1934): Excavaciones en la Albufereta de Alicante (antigua Lucentum). Madrid: Junta Superior del Tesoro Artístico.

Lafuente, J. (1957): Breve historia documentada de Alicante en la Edad Antigua. Alicante: Gutemberg.

Lafuente, J. (1959): Museo Arqueológico provincial de Alicante. Catálogo-guía. Alicante: Instituto de Estudios Alicantinos.

Lillo, P. A. (1981): El poblamiento ibérico en Murcia. Murcia: Univ. de Murcia.

Llobregat, E. (1972): Contestania ibérica. Alicante: Instituto de Estudios Alicantinos.

Lowenthal, D. (1998): El pasado es un país extraño. Madrid: Akal.

Mata, C.; Badal, E.; Bonet, H.; Collado, E.; Fabado, J.; Fuentes, M.; Izquierdo, I.; Moreno, A.; Ntinou, M.y Quixal, D. (2010a): "Comida para la eternidad”. En Mata, C.; Pérez, G. y Vives-FeRRÁNDIZ, J. (eds.): De la cuina a la taula. Saguntum Extra, 9. Valencia, pp. 277-286.

Mata, C.; Badal, E. y Collado, E. (eds.) (2010b): Flora ibérica. De lo real a lo imaginario. Valencia: SIP.

Mata, C. y Bonet, H. (1992): "La cerámica ibérica: ensayo de tipología”. En Estudios de arqueología ibérica y romana. Homenaje a E. Pla Ballester. Valencia: sIP, pp. 117-173.

Miró i Alaix, M. T. (2006): La ceràmica àtica decorada dels segles $v i$ vi a. C. a Empúries. Barcelona: Univ. de Barcelona. 

y la memoria en la necrópolis de La Albufereta, Alicante, en el s. III a. C.

Moratalla, J. y Verdú, E. (2007): “Pebeteros con forma de cabeza femenina de la Contestania ibérica”. En Marín, M. C. y Horn, F. (eds.): Imagen y culto en la Iberia prerromana: los pebeteros en forma de cabeza femenina. Sevilla: Univ. de Sevilla, pp. 339-366.

Morel, J.-P. (1981): Céramique campanienne: les formes. Roma: École Française de Rome.

Mula, M. J. y Rosser, P. (1993): "El poblado ibérico amurallado del Cerro de las Balsas (Albufereta, Alicante): resultados preliminares de los sondeos practicados por el COPHIAM (1990-1991)", LQNT, 1, pp. 105-117.

Muñız, E. (2008): Himnos a Isis. Barcelona: Trotta.

MuñIz, E. (2012): "Isis, diosa del Nilo, y el mar". En Ferrer, E.; Marín, M. C. y Pereira, Á. (coords.): La religión del mar: dioses y ritos de navegación en el Mediterráneo antiguo. Sevilla: Univ. de Sevilla, pp. 145-154.

Nordström, S. (1961): Los cartagineses en la costa alicantina. Alicante: Sucesor de Such, Serra y Cía.

Olcina, M. H.; Guilabert, A. y Tendero, E. (2010): "Lectura púnica del Tossal de Manises (Alicante)", Mainake, 32 (1), pp. 229-249.

Olcina, M. H.; Guilabert, A. y Tendero, E. (2014): "Fortificaciones tardorrepublicanas de Lucentum (Hispania Citerior)". En Sala, F. y Moratalla, J. (eds.): Las guerras civiles romanas en Hispania. Una revisión histórica desde la Contestania. Alicante: Univ. d'Alacant, pp. 127-137.

Olcina, M. H.; Guilabert, A. y Tendero, E. (2017): "Una ciudad bárquida bajo Lucentum (Alicante). Excavaciones en el Tossal de Manises". En Prados, F. y Sala, F. (eds.): El Oriente de Occidente. Fenicios y púnicos en el área ibérica. Alicante: Univ. de Alicante, pp. 285-327.

Olcina, M. H.; Guilabert, A. y Tendero, E. (2020): El Tossal de Manises-Lucentum. Entre los Barca y los Omeyas. Alicante: MARQ.

Olmos, R. (1996): "Signos y lenguaje en la escultura ibérica. Lecturas conjeturales”. En Olmos, R.: Al otro lado del espejo: aproximación a la imagen ibérica. Madrid: Lynx, pp. 85-98.

Olmos, R. (1999): "Usos y transformaciones de la cerámica griega entre los iberos: los ss. v y iv a. C.”. En Villanueva, M.-C.; Lissarrague, F.; Rouillard, P. y Rouveret, A. (coords.): Céramique et peinture grecques. Modes d'emploi. Paris: La Documentation Française, pp. 425-438.

Ediciones Universidad de Salamanca / @థ@्ब
Olmos, R. (2000-2001): "Diosas y animales que amamantan: la transmisión de la vida en la iconografía ibérica", Zephyrus, LIII-LIV, pp. 353-378.

Olmos, R. (2006): "Signo, contexto, comparación, diacronía. Caminos de aproximación a la imagen ibérica”. En Massa-Pairault, F.-H. (dir.): L'image antique et son interprétation. Roma: École Française de Rome, pp. 159-171.

Olmos, R. (2007): "El lenguaje de la diosa de los pebeteros: signo icónico y función narrativa en dos tumbas de La Albufereta (Alicante)". En Marín, M. C. y Horn, F. (eds.): Imagen y culto en la Iberia prerromana: los pebeteros en forma de cabeza femenina. Sevilla: Univ. de Sevilla, pp. 367-389.

Olmos, R. y Tortosa, T. (2010): "Aves, diosas y mujeres". En Chapa, T. e Izquierdo, I. (coords.): $L a$ Dama de Baza: un viaje femenino al Más Allá. Madrid: Ministerio de Cultura, pp. 243-257.

Pena, M. J. (1987): “Los 'thymiateria' en forma de cabeza femenina hallados en el NE de la Península Ibérica", Revue d'Études Anciennes, 89 (3-4), pp. 349-358.

Pena, M. J. (2007): "Reflexiones sobre los pebeteros en forma de cabeza femenina”. En Marín, M. C. y Horn, F. (eds.): Imagen y culto en la Iberia prerromana: los pebeteros en forma de cabeza femenina. Sevilla: Univ. de Sevilla, pp. 17-40.

Picazo, M. (1977): Las cerámicas áticas de Ullastret. Barcelona: Univ. de Barcelona.

PrÊtre, Cl. (1999): "Le matériel votif à Délos. Exposition et conservation", Bulletin de Correspondance Hellénique, 123 (2), pp. 389-396.

Quesada, F. (1997): "Jjinetes o caballeros? En torno al empleo del caballo en la Edad del Hierro peninsular”. En La guerra en la Antigüedad. Una aproximación al origen de los ejércitos en Hispania. Madrid: Ministerio de Defensa, pp. 185-194.

QuesAdA, F. (2011): "El armamento en un poblado ibérico del s. Iv a. C. Una oportunidad excepcional”. En Bonet, H. y Vives-Ferrándiz, J. (eds.): La Bastida de les Alcusses 1928-2010. Valencia: sIP, pp. 196-219.

Ramón, J. J. (2007): "Un fragmento de escultura ibérica procedente del Tossal de Manises". En AbaD, L. y Soler, J. A. (eds.): Arte ibérico en la España mediterránea. Alicante: Univ. de Alicante, pp. 103-110.

Rosser, P. y Fuentes, C. (2007): Tossal de les Basses. Seis mil años de historia de Alicante. Alicante: Ayto. de Alicante.

Rosser, P. y Ortega, J. R. (2008): "El yacimiento del Tossal de les Basses (Albufereta, Alicante) y el hallazgo de una terracota de barco". En Esquembre, M. A. y

Zephyrus, LXXXVIII, julio-diciembre 2021, 111-134 
Ortega, J. R. (coords.): Surcando el tiempo. Un barco de terracota de época ibérica (Tossal de les Basses, Alicante). Alicante: MARQ, pp. 13-35.

Rouillard, P. (1976): "Fragmentos de cerámica griega en la antigua Contestania", Revista del Instituto de Estudios Alicantinos, 18, pp. 9-11.

Rubio, F. (1986): La necrópolis ibérica de la Albufereta de Alicante (Valencia, España). Valencia: Academia de Cultura Valenciana.

Ruiz, A.; Molinos, M.; Rísquez, C.; Gómez Cabeza, F. y Lechuga, M. A. (2015): "La cámara de Piquía, Arjona”. En Ruiz, A. y Molinos, M. (eds.): Jaén, tierra ibera. 40 años de investigación y transferencia. Jaén: Univ. de Jaén, pp. 357-374.

SalA, F. (1998): "Los problemas de caracterización del s. III a. C. en yacimientos de la Contestania", Arqueo Mediterrània, 4, pp. 29-48.

Sala, F. y Verdú, E. (2014): "Pebeteros en forma de cabeza femenina en la Contestania. Estado de la cuestión y perspectiva de estudio". En Marín, M. C. y JimÉnez, A. M. (coords.): Imagen y culto en la Iberia prerromana II: los pebeteros en forma de cabeza femenina. Sevilla: Univ. de Sevilla, pp. 19-34.

Sánchez Meseguer, J. L. y Quesada, F. (1991): "La necrópolis ibérica del Cabecico del Tesoro (Verdolay, Murcia)". En Blánquez, J. J. y Antona, V. (eds.): Congreso de Arqueología Ibérica: las necrópolis. Madrid: UAM, pp. 349-396.

Sfameni, G. (2007): "The Hellenistic face of Isis: Cosmic and saviour goddess". En Bricaul, L.; Versluys, M. J. у Меувоом, P. G. P. (eds.): Nile into Tiber. Egypt in the Roman world. Leiden: Brill, pp. 40-72.

Sparkes, B. y Talcott, L. (1970): The Athenian Agora XII, 1-2. Black and plain pottery of the $\mathrm{VI}^{\text {th }}$, $V^{\text {th }}$ and $\mathrm{IV}^{t^{\text {th }}}$ centuries $B C$. Princeton: PUP.

Trías, G. (1967): Cerámicas griegas de la Península Ibérica. Valencia: Bryant Foundation.

Turcan, R. (2007): "Isis gréco-romaine et l'hénothéisme féminin”. En Bricaul, L.; Versluys, M. J. y Мечвоом, P. G. P. (eds.): Nile into Tiber. Egypt in the Roman World. Leiden: Brill, pp. 73-88.

Uroz, H. (2004-2005): "Sobre la temprana aparición de los cultos de Isis, Serapis y Caelestis en Hispania", Lucentum, 23-24, pp. 165-180.

Verdú, E. (2005): Francisco Figueras Pacheco y las excavaciones en la necrópolis ibérica de La Albufereta de Alicante (1934-1936). Alicante: MARQ.

Verdú, E. (2011): Imágenes de vida y muerte. Figuras femeninas de terracota de la necrópolis ibérica de l'Albufereta. Alicante: MARQ.

Verdú, E. (2015): La necrópolis ibérica de l'Albufereta (Alacant): ritos y usos funerarios en un contexto de interacción cultural. Alicante: Univ. de Alicante.

Verdú, E. (2018): "Pioneros de la arqueología alicantina. La necrópolis de L'Albufereta”. En España, S.; Arranz, R. y Romero, A. (eds.): Colecciones, arqueólogos, instituciones y yacimientos en la España de los ss. XVIII al XX. Oxford: Archaeopress, pp. 154-181. 